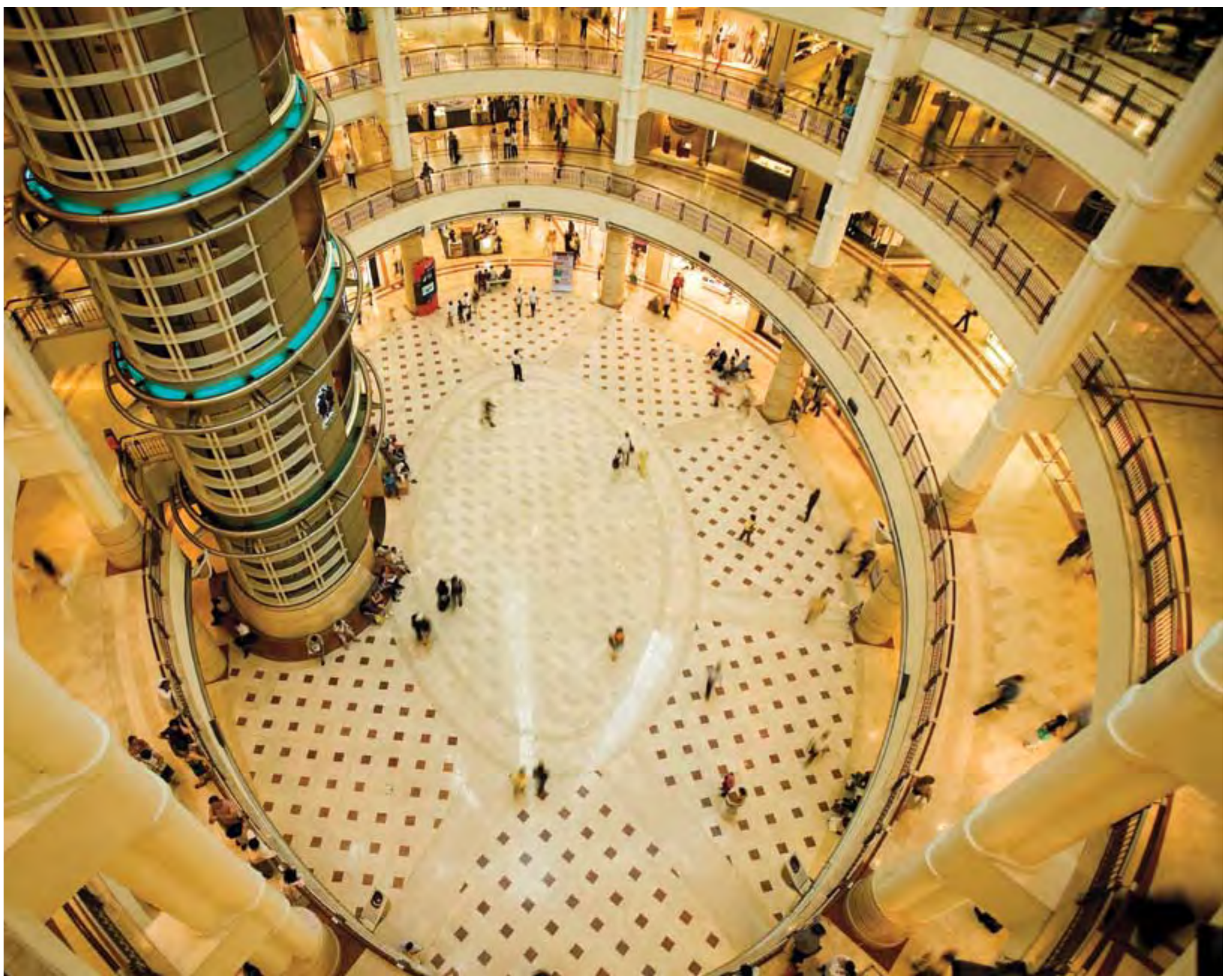

Retailing 2015: New Frontiers 


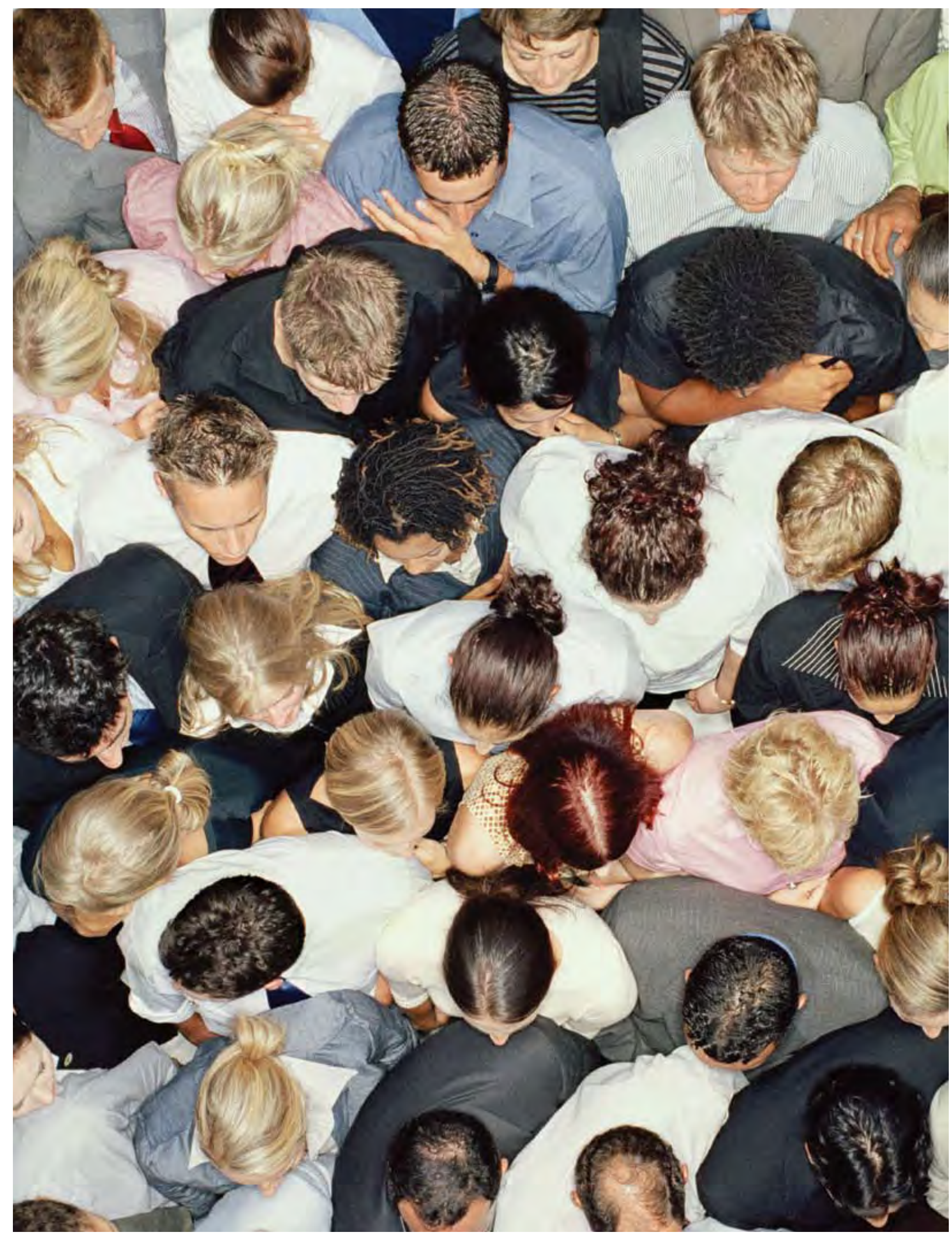


PricewaterhouseCoopers and TNS Retail Forward are pleased to collaborate in bringing you this overview of the retail industry through 2015.

Retailing 2015 confirms that the retail industry is becoming more complex and changing at an ever-increasing speed. Shifting demographics, household downsizing, more educated consumers, new channel formats-among other trends - require that the industry quickly adjust and modify existent models, approaches and processes to satisfy the needs of future customers in order to be successful and profitable. Retailing will become an industry that realizes, more and more, that it must tailor its offerings to select customers, as opposed to the mass appeal approach of the 1980s, in order to win over customers and foster greater customer loyalty.

Changing Demographics: The Baby Boomers have always been a defining generation and will continue to be so. We believe that the Baby Boomer generation will age with increased financial resources and with a greater emphasis on youth and vitality than previous generations. As a result, they not only will tax manufacturers to adapt products to their specific post-retirement needs, but also will require retailers to respond to their evolving needs as they approach the age of 70 in 2015.

Challenging this older generation will be Generation $Y$ (Gen $Y$ ) households, reaching their prime household formation years and attempting to emulate the lifestyle that their Baby Boomer parents have and to which they are accustomed. Gen $Y$ is a more diverse group in how they shop, where they shop and how they spend their money. As a result, Gen $Y$ will represent a challenge to traditional retailing.

Overlaying these changing demographic patterns will be an even greater shift to multi-culturalism throughout the country. Retailers will need to respond to the tastes, customs, interests, and spending habits of an increasingly diverse population with money to spend. Look for many diverse cultural offerings to become mainstream in the future.

The New Consumer: The evolving consumer in the near future will not be easy for retailers to understand or master. The value proposition guiding their product purchases is changing; consumers will put heightened emphasis on personalization, look for opportunities where their input matters, and value product and service solutions. Consumers are increasingly proactive in their purchase decisions and selective about with whom they want to do business. Additionally, consumers will increase their focus on purchasing products from socially responsible and "greenfriendly" manufacturers and retailers. 
Retail Outlets: Retailing, at one time, might have been all about "location, location, location," but the 2015 retail industry will be significantly different from that of today. The U.S. shakeout in conventional malls will continue with a throwback to neighborhood shopping centers catering to very specific tastes. Shopping will become more experiential; eating, being entertained and "living" the shopping experience will take on prominence. The global market will grow rapidly in our flat world, with markets such as China and India granting access to the world's best retailers. By 2015, the retail landscape by country will be dramatically different from today. We envision a knowledge revolution in global markets where the successful retailers will be transferring their best retail practices from one territory to another.

Strategic Outsourcing: Adapting to the changing retail environment anticipated by 2015 will require more flexibility than ever by industry players. While the outsourcing of basic goods is projected to grow in the global economy, companies also are adopting approaches for the outsourcing of non-core competencies-e.g., new product development, software development, business process outsourcing and talent sourcing across national boundaries. Cost efficiencies aren't the only benefits of pursuing strategic outsourcing-management's attention is focused on key business issues, time-to-market may be collapsed, new alliances may be formed, and an understanding of the inner workings of developing and emerging market cultures may be learned. We believe that leading retail companies will be embracing this approach as we move toward 2015.

Targeted Collaboration: In order to reduce the many obstacles that naturally occur between retailers and suppliers, and to overcome a lack of partnership between the two, the retail industry is moving toward creating greater beneficial value through targeted collaboration. To achieve better alignment of goals and drive greater efficiency, retailers and suppliers are becoming trading partners, sharing details and processes on such things as product launches, trade promotions, inventory management and supply chain operations. As collaborative strategic efforts have been proven to deliver joint value, we believe this trend will continue and increase in importance during the next several years.

- The Importance of Technology: Technology is greatly contributing to improved operational efficiency for retailers, but the importance of technology to future business success will become greater. There is, and will be, an overwhelming need to effectively manage the business through business intelligence. Demand-based management can succeed only with real-time data information delivered through increasingly newer forms of technology delivery systems. As a result, retailing will become more personal, and customer data and relationships will become a key asset for retailers. 
- Security and Privacy: Information sharing will reach new levels in the industry. As the retail industry moves to implement an "intelligent" value chain based on the exchange of data across the entire supply chain - resulting in greater efficiencies and just-in-time inventory management - the need for retailers to protect and provide security around customer information will be paramount. Should personal data on product purchases, preferences, styles, etc., be used without permission, customers will deny retailers the use of this data by disallowing the sharing of personal information. The security of personal purchase data will become a critical retail issue going forward.

With the accelerating pace of change and transformation expected for the retail industry through 2015, we are excited about the prospects for the future retail marketplace. Perhaps, more than in past years, the convergence of a number of anticipated drivers will fashion a new retail environment that will build upon the strengths of the retail industry, yet encompass new approaches, models, processes and technologies. These advances will change the retail landscape and add more excitement to a business that thrives on enticing customers, through innovation and personal appeal, to purchase goods and services. Branding one's business to deliver a unique selling experience will continue to remain a highly important ingredient for long-term success.

We hope you find this report informative and insightful.

John G. Maxwell

Americas Retail \& Consumer Industry Leader

PricewaterhouseCoopers, LLP

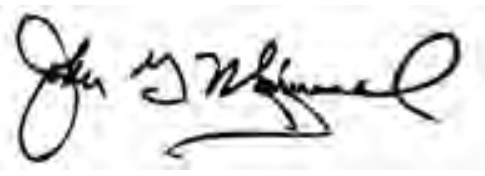

Tom Rubel

President

TNS Retail Forward

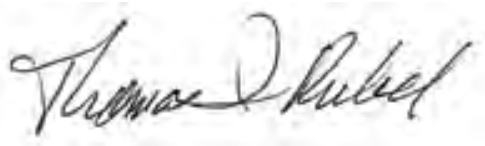

Lisa Feigen Dugal

North American Retail \& Consumer Advisory Leader

PricewaterhouseCoopers, LLP

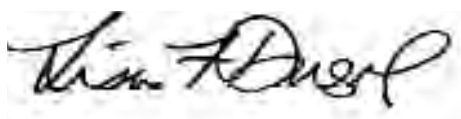




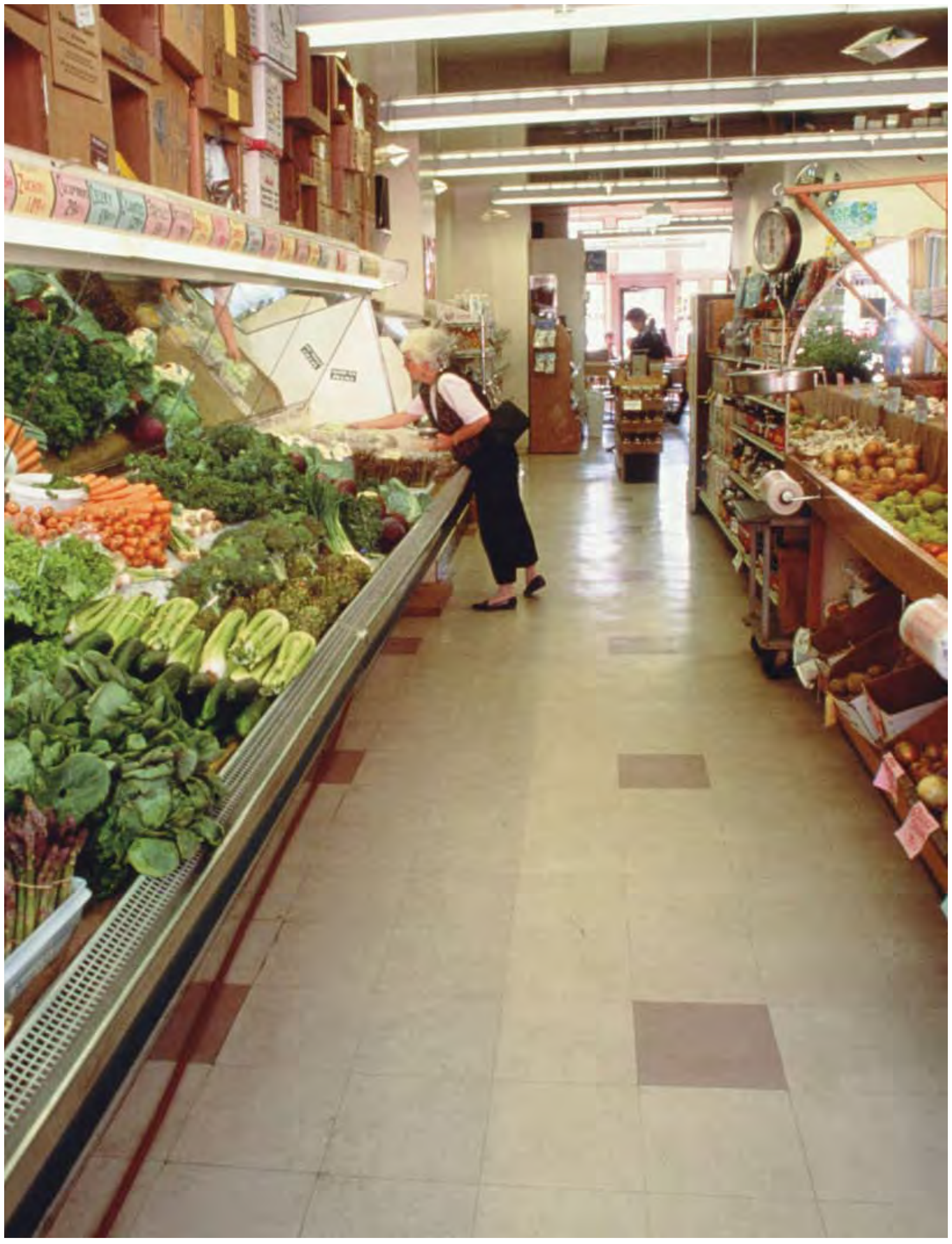


Retailing 2015

15 Facts of Retail Life for 2015-The Evolving Retail Landscape

15 Trends for 2015

Managing Complexity in 2015

Retailing 2015-The Outlook 


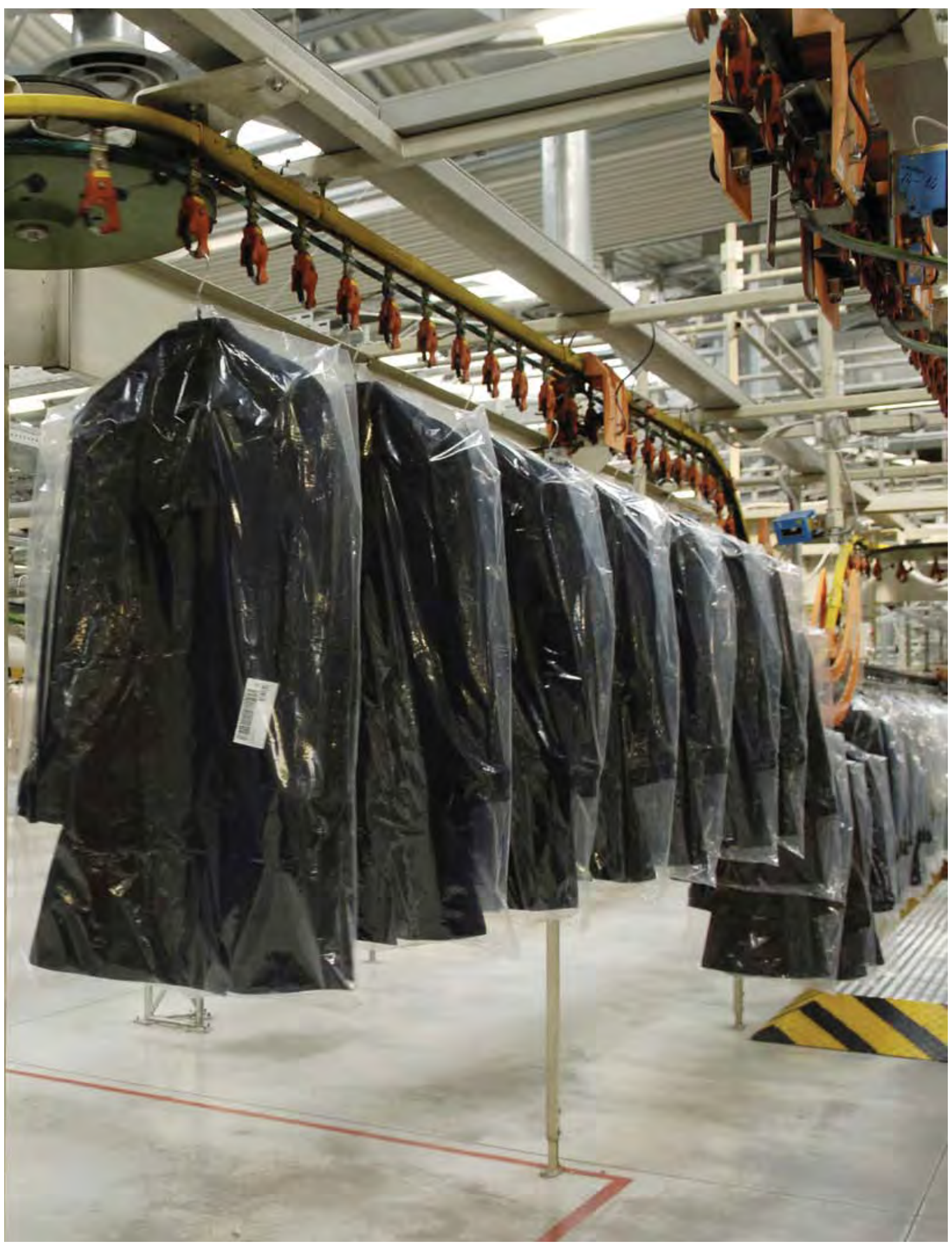


Between now and 2015 will be a time of transition for retailing.

Long-term cycles are coming to a close. New market forces are becoming more prevalent. As these trajectories converge between now and 2015, they will change the retail business environment-and the ways we do businessforever:

- The Baby Boom - which has dominated retail thinking for decades - will stand on the precipice of age 70-and will start turning over the keys to younger generations.

- Interconnectivity will be a part of life-and also a way of life. It will impact the way people get and share information, communicate, transact business, even the way they socialize.

- Many existing retail concepts will reach the end of their expansion runway.

- Spending on services will grow at the expense of spending on goods.

- The prevailing belief that bigger is better will break down-aggregation of small will be the new big. Leading companies will combine global scale with excellence at local execution.

- Global scope has been an option. In 2015, it will be a requirement to support large-scale growth and sound business economics.

- Consolidation of retailing into a global oligopoly will continue, as major players seek expansion in emerging markets experiencing rapid growth of the middle class and rapid modernization of retailing.

- "Point of purchase" will be the battlefield for consumer dollars-replacing the confines of "shelf space" and "selling floor".

- Technology will be pervasive-driven by falling costs, widespread access and adoption, a working infrastructure and increased standardization.

- Retailing will evolve toward true demand-replacing the artificial demand dictated by the limitations of shelf space-in an increasingly digital retail environment where shoppers will have almost infinite visibility into product choice and increasing input into product creation.

- Digital and personal media will continue to grow exponentially and create new channels for customer insight, interaction and engagement.

- The value chain will become more intimate: Consumers will share more information with retailers and suppliers but expect to get more value in return. 
- Just-in-time supply chain and the technology to support it will no longer be the gold standard; extremely reduced cycle times will require accelerated trend identification, entry and exit.

- Consumers won't be able to take resources for granted anymore. Resources will be scarcer, in greater demand and hence more expensive-raising the bar on expectations for corporate responsibility and product sustainability.

The goal of this report is to:

- Explore the change drivers - the assumptions that drive this outlook and the trend lines that will merge to form the new facts of life for retailing in 2015.

- Describe the trends that will dominate the future.

- Identify the critical success factors retailers and suppliers must address to manage the complexity and diversity of retailing in 2015.

To succeed in 2015, retailers and suppliers must remember what got them there-and also embrace new assumptions that drive the new outlook. Past business drivers will wane but won't entirely disappear. New business drivers will become more prevalent. 
As existing patterns play out during the next decade, the retail marketplace will face a very different landscape in 2015. Here are the top 15 facts of retail life in 2015 as we see them:

\section{Demographic Dichotomies}

The period between now and 2015 will be one of demographic dichotomies. Many demographic dichotomies already are under way, but the gaps between shopper segments will widen during the next decade. It will be much more difficult for retailers to bridge these gaps in 2015. To find growth, retailers will need to look at the poles. There will be no safe middle ground. Different ends of the shopper spectrum will require different products, shopping environments and brand strategies. Even if customers at opposite poles want to buy the same things, retailers will not be able to sell to them in the same way, in the same place or with the same message.

Demographic dichotomies will dominate several scales:

Older vs. Younger - Society will hourglass rapidly along the age spectrum, with all of the growth between now and 2015 happening in the older generations or the younger generations (Figures 1 and 2).

Reflecting the path of the Baby Boom bulge, the most rapidly growing age segment in the United States will be 55+. By 2015, leading-edge Baby Boomers will be staring age 70 head on; trailing-edge Boomers will be looking at 50 in the rearview mirror. If 50 was the new 30 , will 70 be the new 50? Do not expect Baby Boomers to go conventionally into maturity. Expect them to redefine older age and retirement, remaining active and involved.

Figure 1

U.S. Population Growth by Age - 2005-2010F, 2010-2015F

(\% change)

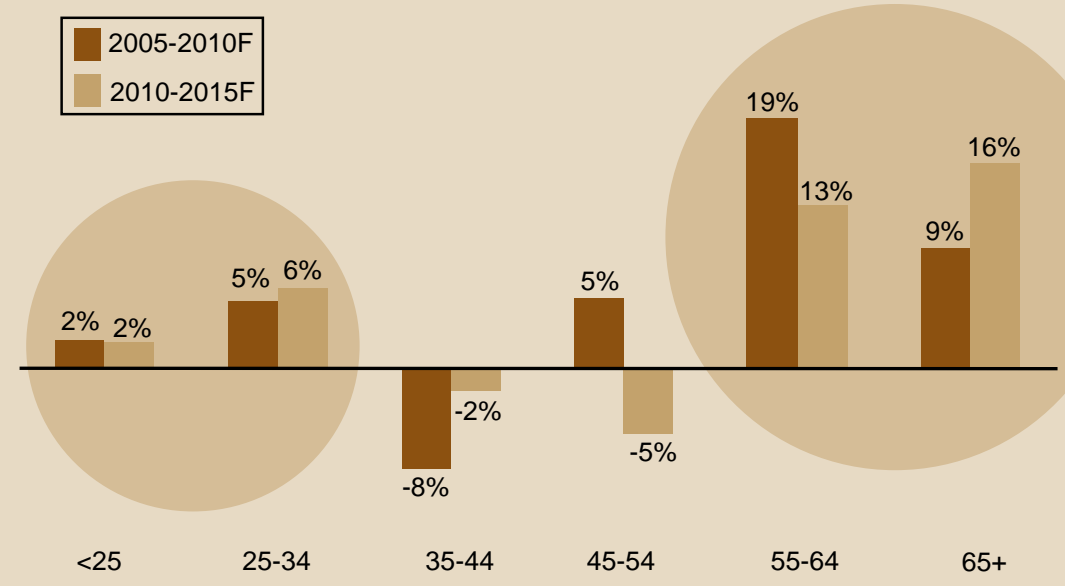

Source: U.S. Census Bureau 
There will also be growth at the younger end of the age spectrum, among customers younger than age 35-the Gen $Y$ and Millennial cohorts. Gen $Y$ will reach its prime household formation years. Like their Baby Boomer parents, members of Gen $Y$ are shoppers, but they are more diverse, less enamored of large conglomerates and chain stores, more interested in entertainment and recreation, and more likely to be multichannel shoppers.

The Millennials will traverse the teen years. This generation's mindset and approaches to the marketplace will be radically different from preceding generations. Diversity is just a part of who they are. Technology is part of their DNA.

Multi-Cultural vs. Mainstream - Another key demographic dichotomy is the growth of multi-cultural America compared with mainstream America. The U.S. population will be more diverse by 2015, as the population tilts towards younger cohorts, which are more diverse than older cohorts (Figures 3 and 4).
Figure 2

Generations as a Percent of the U.S. Population, 2015F

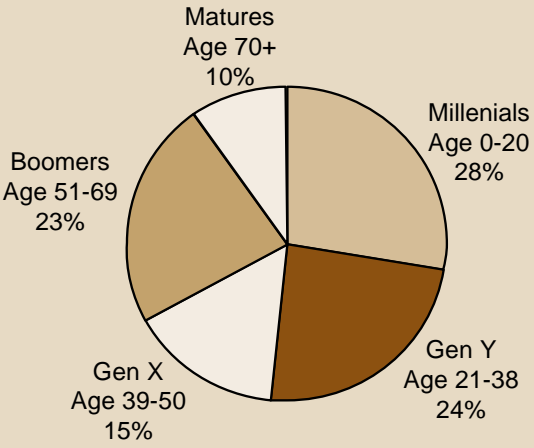

Source: U.S. Census Bureau

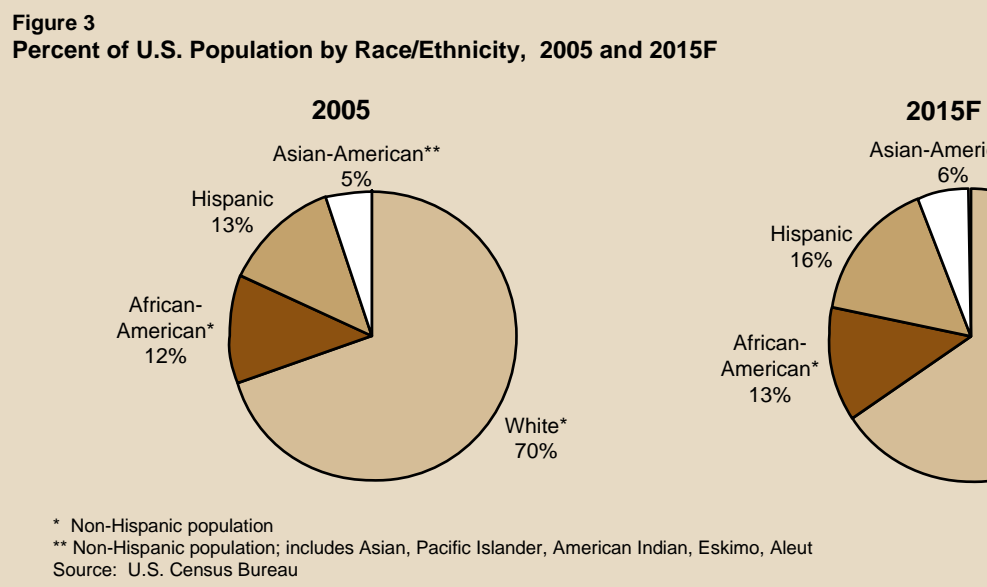

2005

* Non-Hispanic population

** Non-Hispanic population; includes Asian, Pacific Islander, American Indian, Eskimo, Aleut

Source: U.S. Census Bureau

Figure 4

Distribution of Age Ranges in the United States by Race/Ethnicity, 2015F

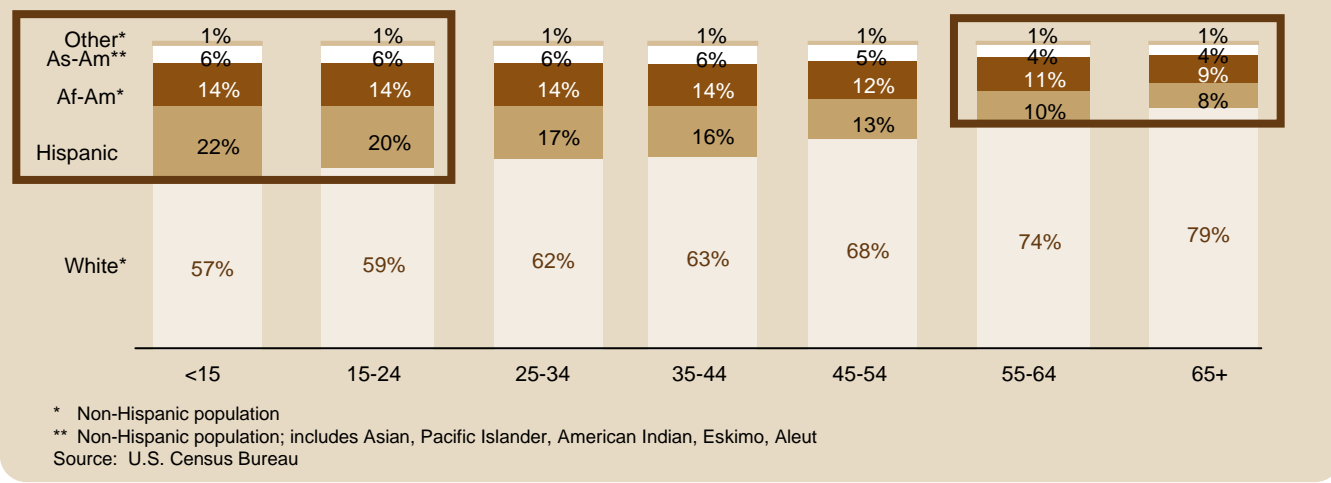




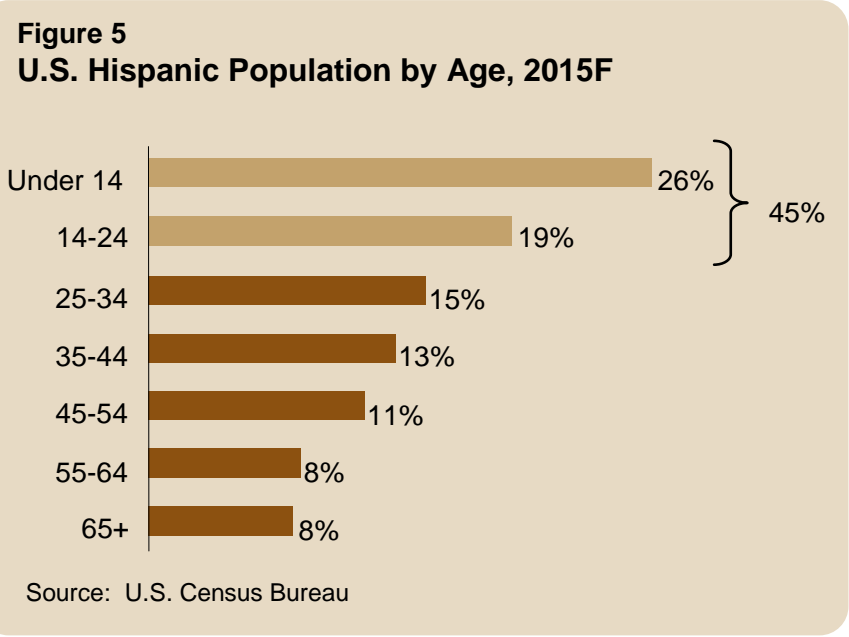

\section{Figure 6}

Average Number of Persons per Household in the United States, 1995-2015F

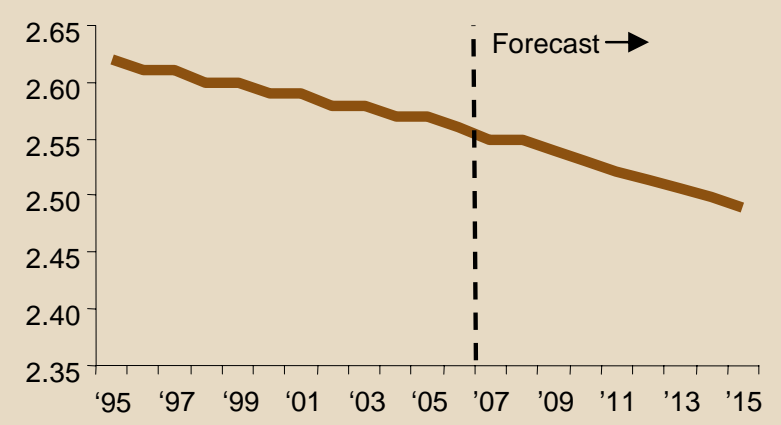

Sources: U.S. Census Bureau and The Brookings Institute
The population explosion and geographic dispersion of Hispanics is a key driver of diversity in younger generations. While less than one-fourth of the population age $55+$ will be non-white in 2015, nearly half of the Hispanic population will be younger than 25 (Figure 5). Among younger generations, diversity itself becomes the mainstream-part of the definition of who they are.

\section{Families vs. Households - By 2015, there will be more} smaller households of one or two persons, and fewer traditional family households due to the aging population, empty nesters, and singles young and old (Figures 6 , 7 and 8). Opportunities will abound for smaller, more personalized products and living spaces, and for experiences that are fun for one.

\section{Figure 7}

Family Households as a Percent of Total U.S. Households, 1995-2015F

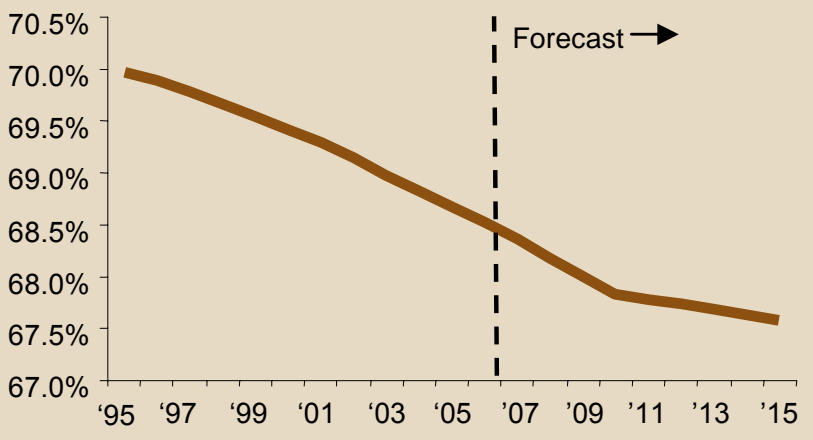

Sources: U.S. Census Bureau and The Brookings Institute

\section{Figure 8}

Percent of U.S. Household by Type

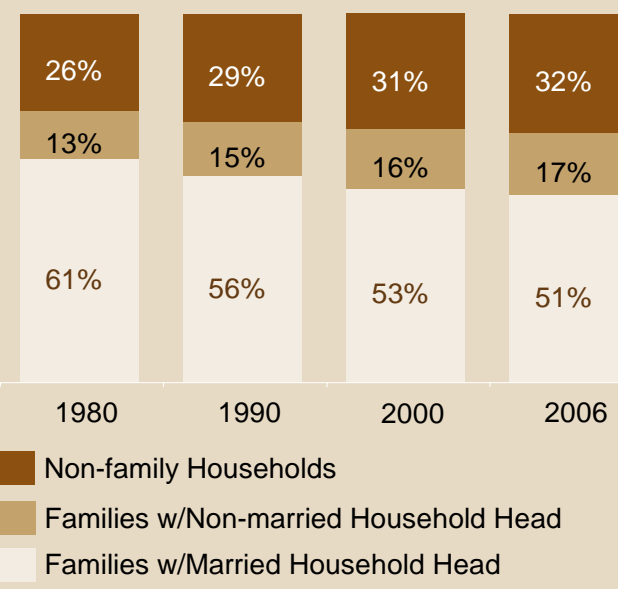

Sources: U.S. Census Bureau and The Brookings Institute 
Redeploying vs. Shouldering - During the next decade, Baby Boomers will begin to exit the work force and redeploy their vast energies and spending power. In their stead, younger generations will shoulder the burden in the work force and in the retail marketplace.

Growth of the labor force will slow as Baby Boomers exit and the smaller generations that follow cannot make up the gap. The loss of workers will be particularly acute in the middle management ranks, as the overall number of workers aged 35-54 contracts (Figure 9).

Some of this loss will be offset by the large younger generation entering the workforce. However, most of these employees will be "early-curve" workers who have not yet developed the skills and experience base to fortify the ranks of midlife workers.

Some of the loss will be offset by Baby Boomers who remain in the labor force either by economic necessity or by choice. However, many Baby Boomers will be "late-curve" workers who are either too expensive or too highly skilled for mid-career roles. Others will opt out of traditional work roles, preferring to pursue their own business interests or to cycle between periods of work and leisure on an as needed or as desired basis.

- Thriving vs. Surviving - The coming decade will also witness a widening gap between haves and have-nots in terms of wealth, education and techno-literacy. The top $10 \%$ of households will account for a growing share of total income (Figure 10). Baby Boomers will represent a microcosm of have vs. have-not in the form of prepared vs. unprepared for retirement. The Baby Boom will be the first generation to retire with $401 \mathrm{Ks}$ instead of pensions. Some will work because they want to; some will work because they have to.
Figure 9

Numeric Change in U.S. Labor Force by Age (000s), 2004-2014F

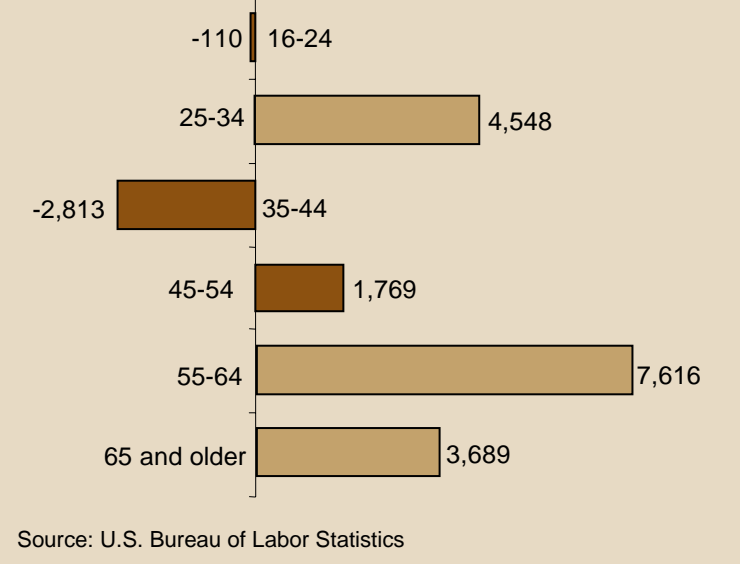

Figure 10

Top Decile Share of Household Income, 1980-2005

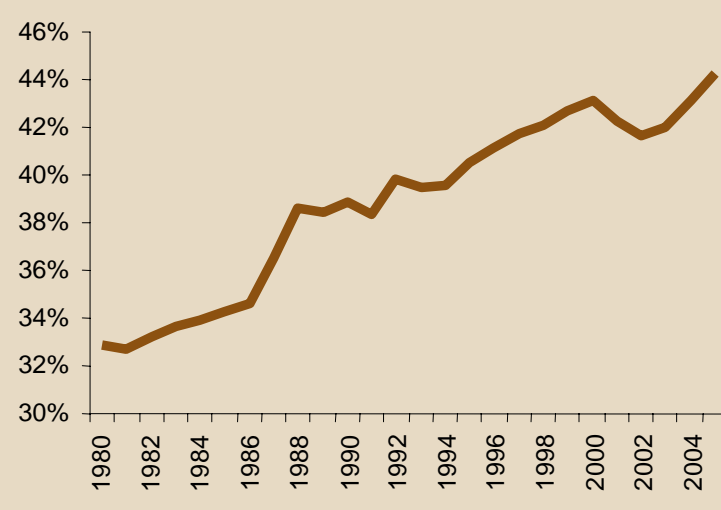

Source: March 2007 Saez and Piketty analysis of tax return statistics, University of California, Berkeley 


\section{As consumers age:}

Softgoods take the earliest and biggest hits

Homegoods and consumables soon follow

Healthcare is the only bright spot

\section{Disruptive Waves}

Between now and 2015, the biggest consumer causes of disruption in the retail marketplace will be First-Wave Boomers and the Digital Generation (Second-Wave Gen Y and First-Wave Millennials, collectively). The aging of the Baby Boom will affect the ability of many retailers to grow and prosper. The coming of age of the Digital Generation will affect how retailers can grow and prosper.

\section{First-Wave Boomers - As they approach age 70, First-Wave Baby} Boomers will be reaching a lifestage where spending on many goods begins to decline (Figure 11). They will have new needs, driven by smaller households, increased emphasis on health and general welfare, and increased service demands as "help me" replaces "DIY." They will have new requirements-smaller, closer, easier. And they will have new desires, such as quality of life, experiences, entertainment, enrichment, leisure and legacies. Compared with previous generations of retirementage consumers, First-Wave Boomers will be more highly educated, more economically empowered and more self-focused. The biggest difference will be among female Boomers, as the first retirement generation of women who have had significant careers, strong earning power and confidence in their abilities-driving high expectations for a productive senior lifestage.

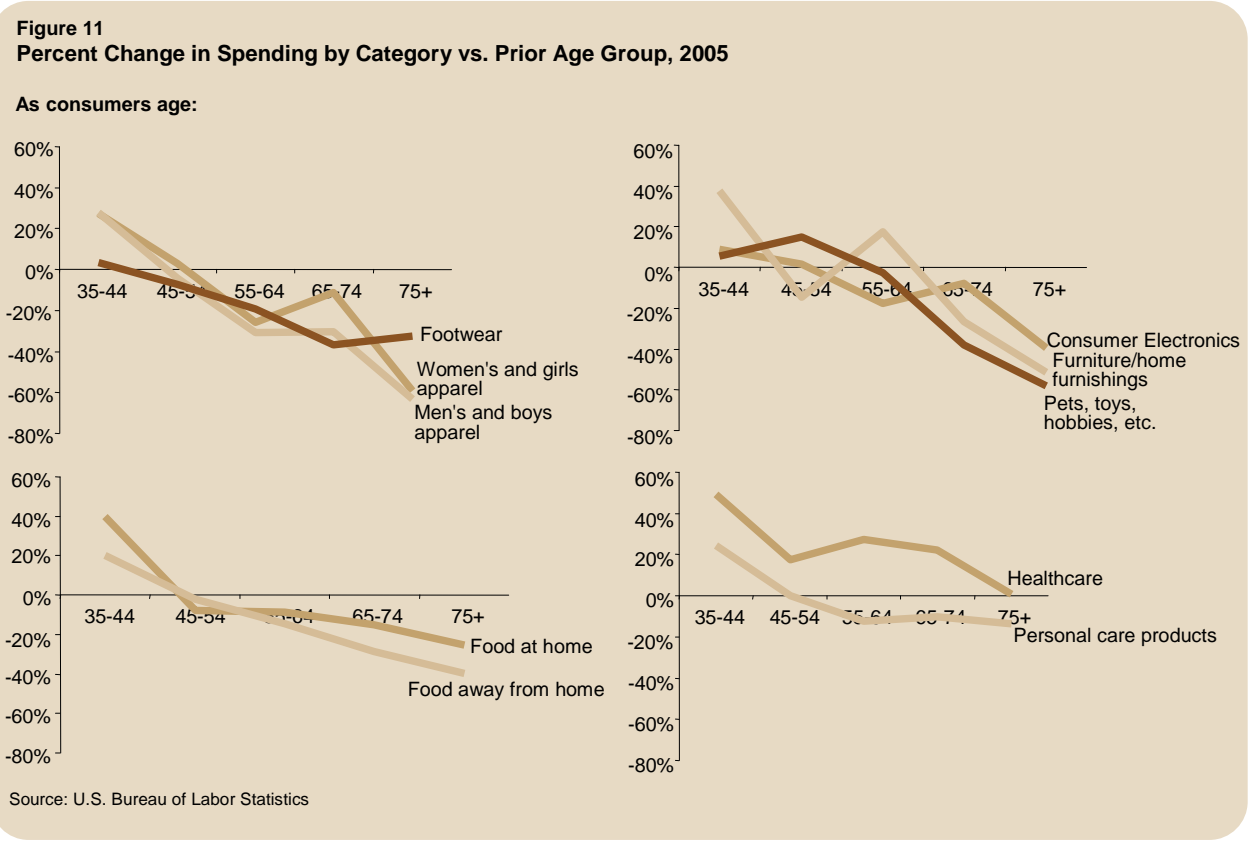


Retailers and suppliers will need to respond with offers that are age- and attitude-appropriate, but take into account the inevitable changes in priorities that occur with maturity - focusing on products, services and experiences that help Boomers defy, deal with or enjoy age.

First-Wave Boomers will also have a new credo as "I don't get anyone under 30" replaces youth's rallying cry of "I don't trust anyone over 30."

The Digital Generation - It has been about 50 years since rock ' $n$ ' roll ignited a generation gap between young people and their parents. Today, there is a new generation gap looming, driven by the digital "divide" (Figure 12). Growing up in a world where there are very few physical or psychological barriers to trying new ways to do things, the Digital Generation will epitomize the new mindset of the decade: everything is interconnected, anything goes, everything is available, and nothing is private. They will be savvy, skilled shoppers, who place a high level of importance on individualism, self-fulfillment and personal involvement in the creation process. Retailers and suppliers will need to respond by providing members of the Digital Generation with the tools they need create, co-create or re-create to suit themselves.

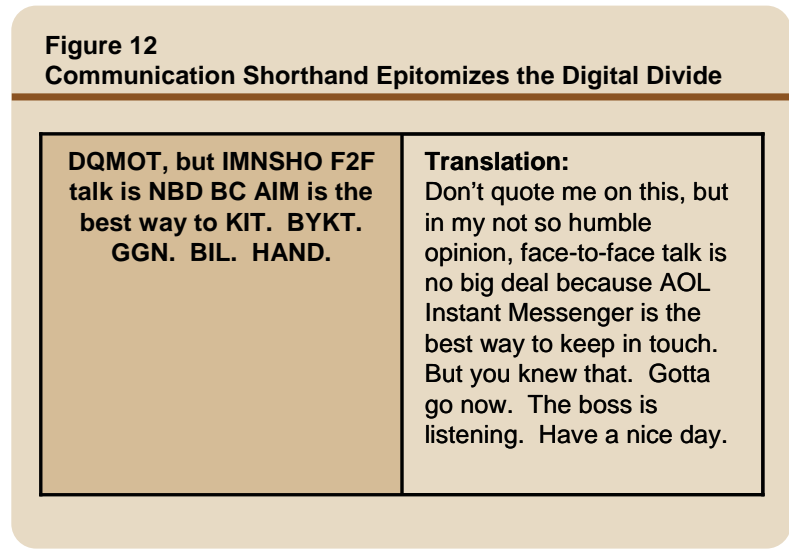

These two disruptive waves will represent a challenge for many retailers and suppliers. Compared with the big-spending Baby Boom generation, new spenders will be less attractive. Fewer will have reached their bigspending lifestages. They will have less buying power. They will be more fragmented into niche interest markets. They will demand more personalization. They will be harder to reach with conventional media, marketing and formats. 


\section{New Consumer Mindset}

A new set of underlying drivers will permeate our society and our shopping behavior. Four mindset mega-trends will have far-reaching implications for the retail marketplace of 2015:

Interconnected-By the middle of the next decade, interconnectivity will be a part of life. Consumers will expect to connect to anyone, at any time, about anything, from anywhere. Interconnectivity will also be a way of life - the way people get and share information, communicate, transact business, even the way they socialize. Social status in the next decade will become much more about who you connect to and who wants to connect to you. Expect an explosion of social networking sites designed to expand the individual's reach.

- In Control - With interconnectivity as a base assumption, consumers also will become more adept at controlling the ways in which they interact. Control will take three forms:

- Clout control-Consumers will find there is strength by association to drive change. Crowd clout will help consumers demand the products they want, via the shopping experience they want, from companies that do business in the ways they want.

- Context control-Tools and technologies that enable time-shifting and place-shifting increasingly will allow consumers to capture information, communicate and conduct transactions regardless of the time or the place.

- Contacts control-Consumers also are gaining more control of whom they let into their interconnected "world." They are increasing their use of filtering mechanisms to create a "closed loop society," where connectivity is limited to the contacts they allow in. Such filtering mechanisms today include spam filters, permission-based marketing, cell phone as primary phone, caller ID and sites where consumers can "reject" unwanted contacts. Expect to see a proliferation in social networks that are more finely focused and, in some cases, more exclusive in the ways people find and join them. Unlike meganetworks designed to extend reach, the goal of these micro-networks is to narrow reach to specific niches of similar interests.

Indulgent-In 2015, consumer indulgence will be focused on the "next new thing" and the "next best thing." Interconnected shoppers will have the tools to easily discover, find, filter and try the next new thing - at ever more affordable prices - and then quickly move on. Given virtually unlimited accessibility to the next new thing, consumer indulgence will shift to the next best thing-niche products, experiences and services uniquely suited to their tastes, interests and aspirations. 
Individualized - Shoppers will gravitate toward products and experiences that offer individual focus, interaction and involvement in the entire value chain process. They will desire products and experiences they perceive as meeting their unique needs. They will want the opportunity to interact at the individual level with retailers and suppliers. Taken to the extreme, they will seek out opportunities for involvement in the entire chain of activities that brings a product to market-from conception, design and creation, to marketing and retailing, even to funding and rewarding.

\section{Retail Runway Runs Out}

Most major retailers will be out of expansion room in the United States for their core concepts by 2015 . Very few formats will grow at a rate exceeding the overall retail sales growth forecast-and virtually all of those will grow at a slower rate than earlier in the millennium (Figures 13 and 14). Players will need to turn elsewhere for growth - new concepts, new customer segments, new geography, new categories.

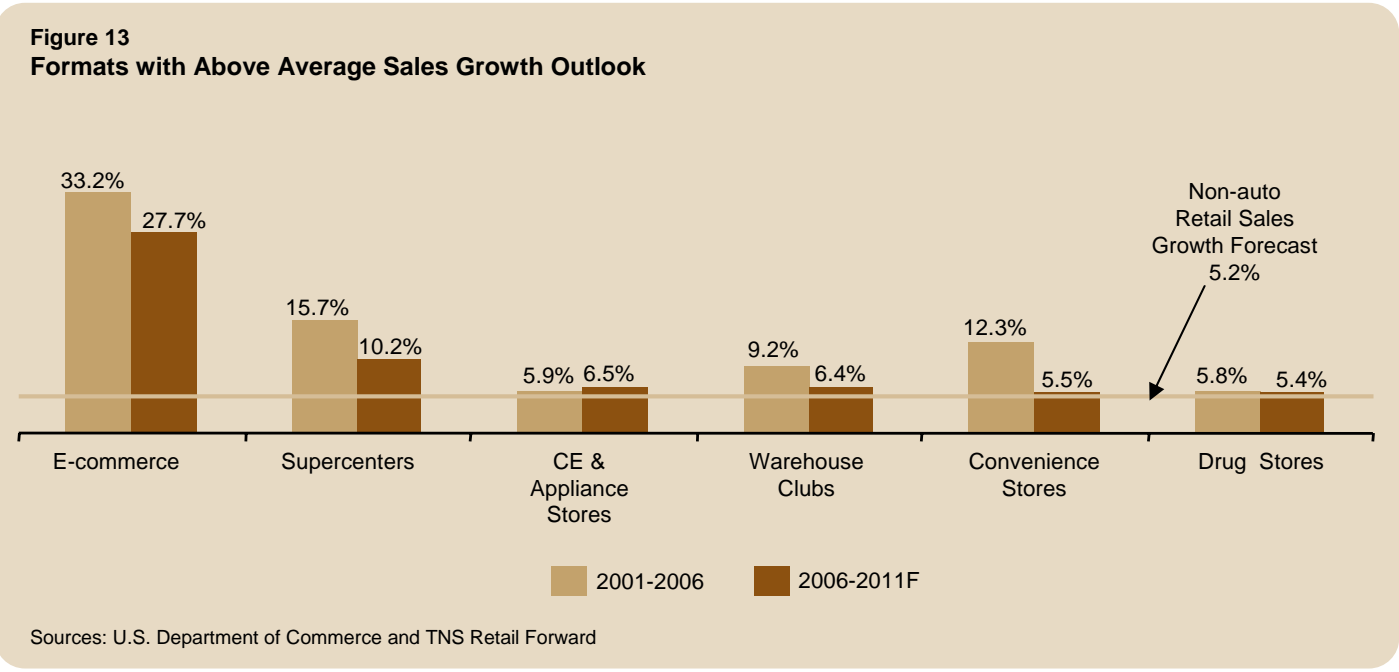

\section{Figure 14}

Formats with Below Average Sales Growth Outlook

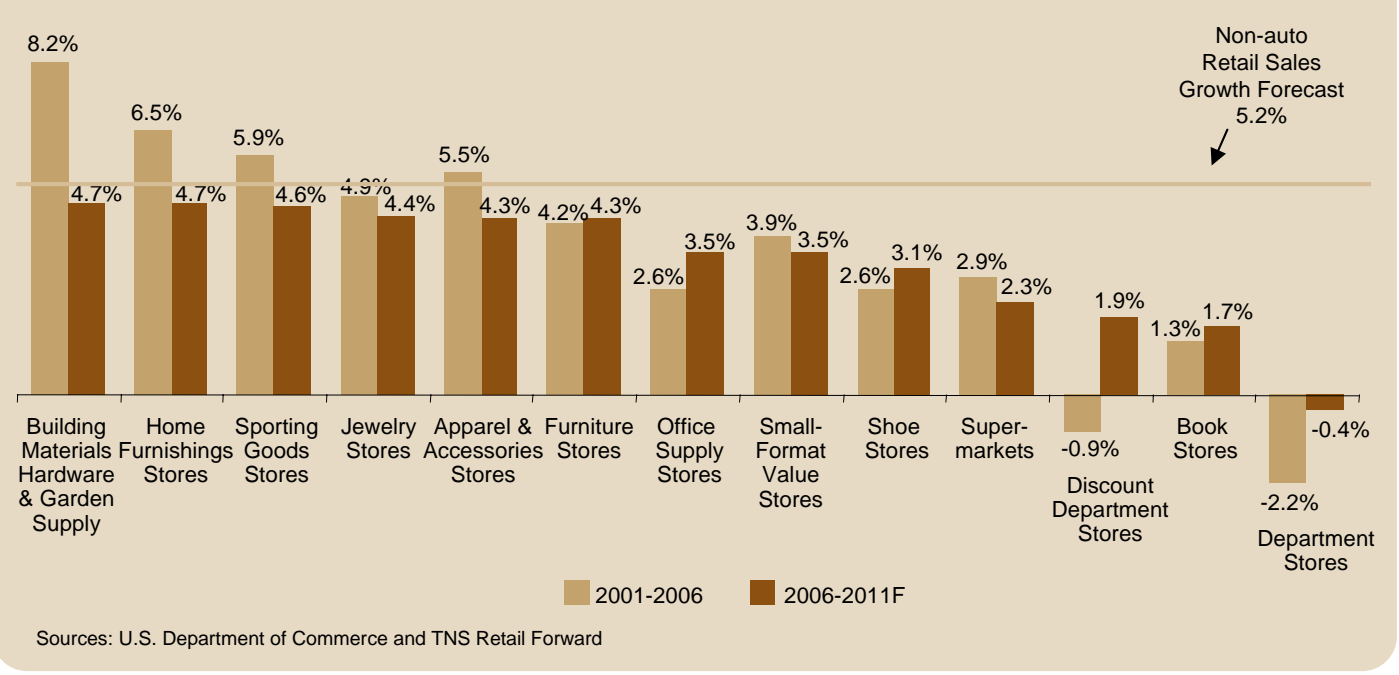




\section{Growth in Spending on Services}

Spending on goods will continue to lose ground to spending on services (Figure 15). Older generations are becoming more service, "do it for me", and experience oriented. Younger generations are more likely to approach goods, services and experiences as an integrated continuum. To satisfy customer needs, retailers will need to incorporate services and experiences into their concepts.

Figure 15

Personal Consumption Expenditures: Goods vs. Services, 1980-2005

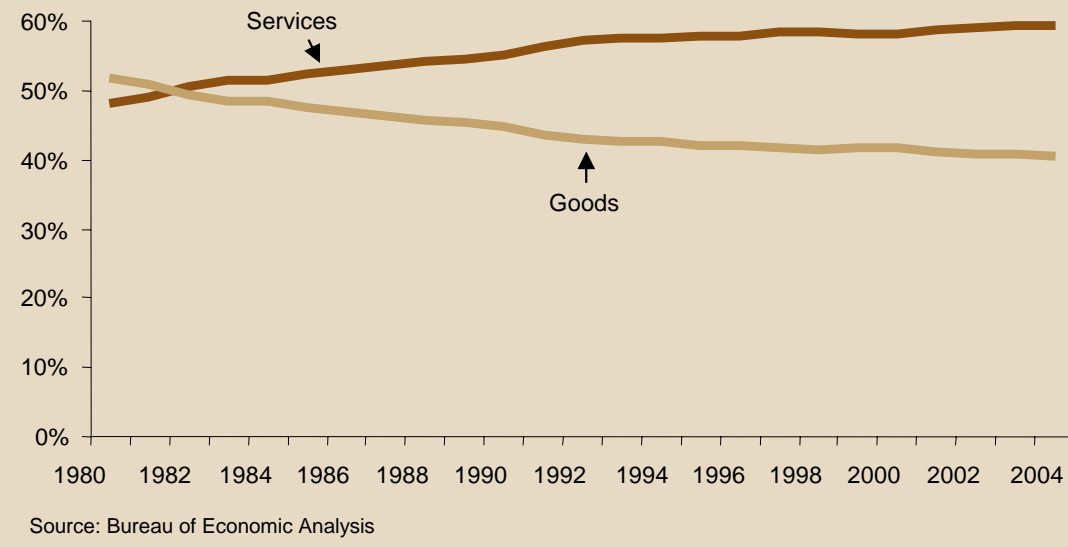

\section{Growth in Nontraditional Spaces}

Between now and 2015, the retail landscape will evolve. The shakeout of marginal malls will continue, fewer conventional malls will be built, fewer existing malls will perform well, fewer shoppers will traffic malls with high frequency, and there will be fewer conventional department stores to go around as mall anchors (Figure 16). More lifestyle and neighborhood

Figure 16

Number of New Regional/Super-regional Malls Opened per Year, 1998-2008P

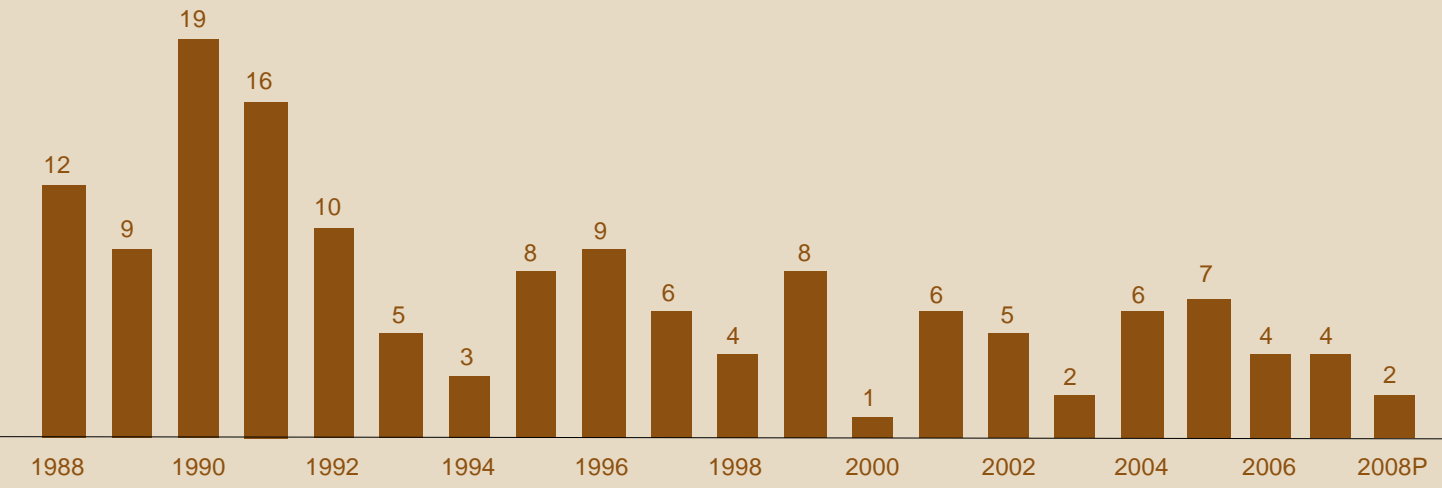

Source: International Council of Shopping Centers 
centers will come on board, where retailing mingles with nontraditional traffic drivers. These will be places where people can go to eat, entertain and live-not just shop. High-performance malls will continue to reinvent and reinvigorate-many by taking a lesson from lifestyle-driven formats. The Internet will exert more influence-continuing to grow rapidly as a retail channel, but, even more importantly, continuing to grow exponentially as the conduit to the vast marketplace outside traditional space.

\section{Growth in Nontraditional Places}

Growth in most developed retail markets will be slow. The fastest growth will take place in developing retail markets, including the huge markets of China and India (Figure 17). Retail issues in developed markets around the globe basically will be a mirror image of issues confronted by the U.S. economy-aging populations, shrinking share of retail spending and increased spending on healthcare. In contrast, populations in developing markets will remain relatively young and will increase share of retail spending. Developing markets will continue to build a big pool of university-educated labor and talent, shifting the nucleus of knowledge workers. Trend-spotters will want to set up camp in developing markets, especially Asia, which will begin to eclipse developed markets as a hotbed of cultural and retail market influence.

\section{True Global Economy}

In 2015, retailers will do business in a true global economy-global customer base, global sourcing, global outsourcing pool, global reach. Barriers to global trade will continue to come down. Impediments to global sourcing will continue to ease. Developing markets will continue to phase out restrictions on foreign retailer operations and liberalize regulation of direct foreign investment.

Global scope will be a necessity, not an option, to grow the top line and bolster the bottom line. Global expansion will be a key avenue for retailers in developed markets to generate new sources of revenue to offset slower sales growth at home. The Internet will provide global customer reach even in the absence of a global footprint. Global sourcing will be a critical component of differentiated assortments at competitive price points. Global outsourcing will be vital to reining in expenses while keeping the business focused on core differentiating capabilities.

Figure 17

Non-auto Retail Sales Growth Outlook, 2006-2011F

Compound average annual growth rates

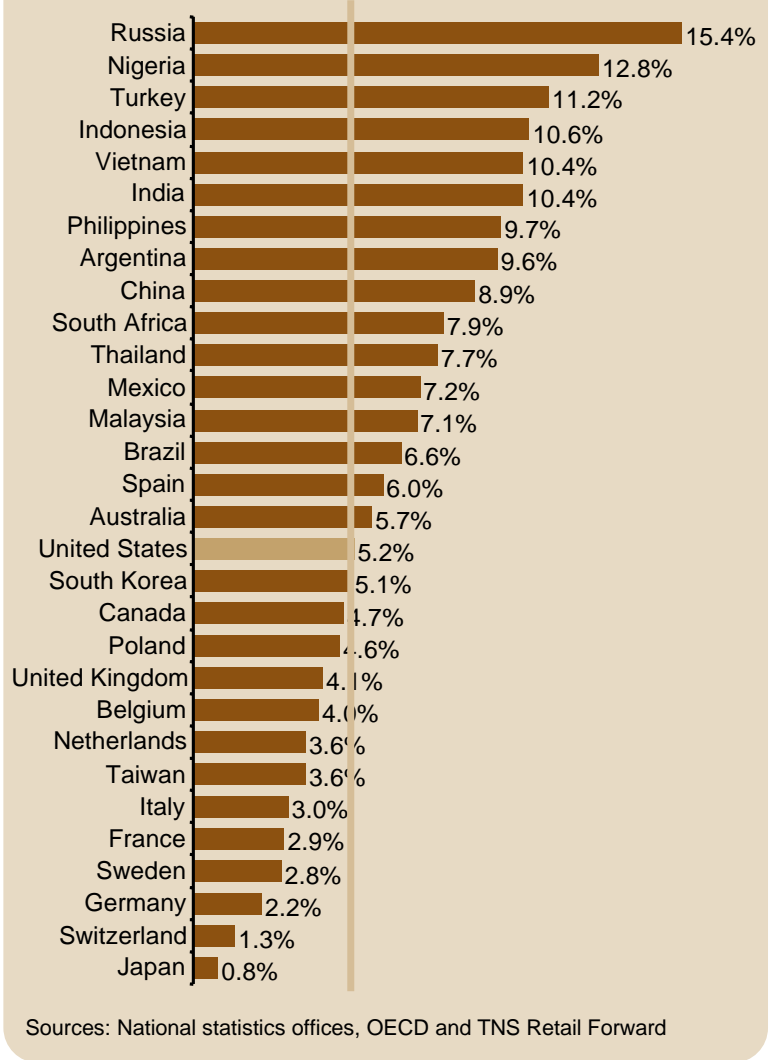




\section{American Retailers Play Catch-up}

To support growth projections, more American retailers will need to expand globally. They will be late to the game, especially compared with large European retailers, which have long operated on an international scale, and local retailers in developing markets, which have been riding the coattails of grassroots opportunity. American retailers will have a harder time getting a foothold in global soil. In many places, American products will no longer be the status symbols they once were, especially as local and developing market influences gain popularity. As middle-class consumers emerge around the globe, the United States will no longer be the main customer for goods and resources. Global expansion will require local partners, personnel, products, and perception into local customers and cultures. American companies will have to play by global standards.

\section{Retail Battleground Redefined}

In 2015, the battleground for retail sales is broader-point of purchase, not just retail shelf or sales floor. The power shifts again. Suppliers dominated the 1980-90s as they pushed product and thrived on national brand pre-eminence. Retailers dominated the 2000s with SKU rationalization, increased private brand penetration and fact-based merchandising decisions. Consumers will dominate in $\mathbf{2 0 1 5}$ as they increase demands for interactivity, segmentation, localization and customization, and as they leverage greater visibility into product availability and pricing. This will require unprecedented levels of value chain collaboration.

The assumption guiding recent decades has been that suppliers will do business with fewer retailers who will carry fewer (inter)national brands. The driving assumption for suppliers in 2015 must be that their large retail customers will operate more but smaller concepts to meet the needs of more diverse consumer segments. They will want the suppliers they do business with to be just as versatile. They will demand the SKUs they carry convey differentiation and credibility while delivering profitable sales. With the decreasing gains from new store openings, retailer and supplier profitability will be achieved by driving greater productivity within existing stores.

\section{Almost Perfect Product Access}

Through much of the history of product distribution, a large part of a product's value has been added at the factory (in the production stage) and at the store (by making the product accessible). In 2015, we will have almost perfect product access - availability of the right product, at the right place, at the right price. The economics of scarcity will give way to the economics of abundance. 
Consumers will be able to get almost any product they want. Surplus manufacturing capacity around the globe will support low-cost product sourcing. More manufacturers in developing countries will add reliable, low-cost production capacity capable of producing to acceptable quality standards worldwide-driving commoditization of quality. Enduring deflation will keep prices in check - driven by rapid growth of price-driven retail formats, the proliferation of private brands, the rise of the global supply chain and the continuing elimination of trade barriers.

Thanks to the Internet and the rapid evolution of search functions and filters to connect supply with demand, consumers will be able to find almost any product they want. Thanks to a range of customization tools and technologies, if they can't find what they want, they will be able to "create" what they want-especially in digital media, increasingly in "real" world media.

\section{Pervasive Technology}

Technology will be pervasive in 2015 . Falling costs, widespread availability and adoption of devices, a working infrastructure and standardization will accelerate the integration of technology. This will drive more change in the way consumers shop in the next 10 years than it has in the last 20 years.

Consumers will have access to devices in home and in hand (Figure 18). Miniaturization will allow mobile devices to add increased functionality and also allow everyday items like accessories to function as devices. Biometric technologies are emerging, including facial and voice recognition and fingerprint, iris and retinal scanning. Interactions will be increasingly natural, such as voice activation. Self-activated agents will perform routine tasks without human intervention.

\section{Figure 18}

Household Penetration of Devices, High-Speed Internet

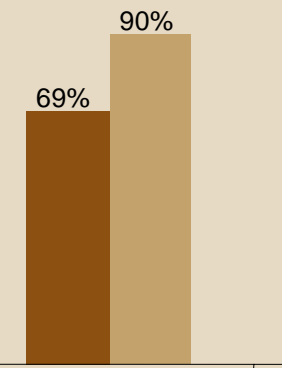

Personal Computer

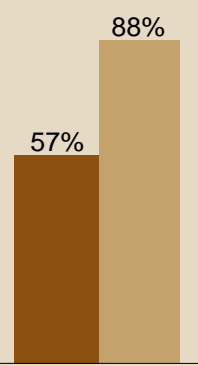

Mobile Phone

\section{$\%$}

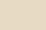

2001

2006

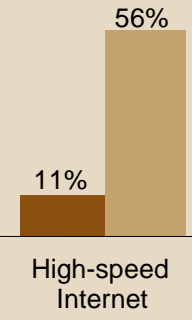

MP3 Player

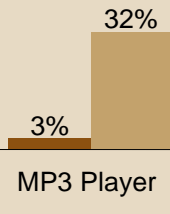

$32 \%$

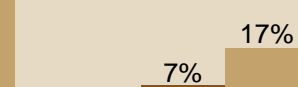

$7 \%$

PDA

Source: Forrester Research, Inc. 
Consumers will be able to access content on demand. Information will be available anywhere, anytime, in any language (instant translation). For retailers and suppliers, technology will empower an unprecedented level of value chain collaboration and communication - from raw material supplier to end user and back again.

\section{No Privacy-No Problem}

In a world of pervasive technology, the advantage will go to those who share-especially to those who make sharing worthwhile. Information sharing will reach new levels: between supplier and retailer, supplier and consumer, retailer and consumer, and consumer and consumer. Value chain collaboration will be critical to drive products and assortments keyed to niche market demand. Expect security issues to be resolved or protections provided-at least to the point that most consumers will feel the risk of sharing is outweighed by the rewards. Consumers will share-so long as there is a good reason to share. If retailers and suppliers do not make sharing worth their while, consumers will bar access, relying on the plethora of filtering mechanisms available to close the loop to unwanted solicitations.

\section{Information Overload}

Retailers will be awash in data. The typical retailer will capture not just product profitability and store and transaction data but also customer data and operating data delivered nonstop by in-store devices. This will give rise to new customer-driven metrics, and new metrics designed to improve the shopper journey and point-of-purchase experience. Expect intensified focus on achieving accounting-quality data for customer and shopper metrics. 


\section{Tougher Standards}

In 2015, retailers and suppliers will be held to higher standards around the globe. Concern about people and planet will no be longer a fad or the domain of the activist few. It will be an integral part of mainstream consumer demand around the globe, buffeted by forces from the rising level of government involvement in what Americans can consume, to the omnipresence of news media (news travels everywhere virtually immediately), to watchdog groups. Environmental causes will remain front-page news - headlining the rising cost of scarce resources, environmental scares such as global warming and health pandemics, the hazards of food and drug contamination, and discovery of the "next thing bad for you." Further globalization efforts will pose a new set of challenges as retailers need to deal with different-and often strictercultures, value systems, legislative environments and reporting requirements abroad. With pervasive technology, what retailers and suppliers do-how they do it-wherever they do it-will be more transparent to their constituencies around the globe. 
If these are the drivers, then what are the outcomes? What will the retail landscape look like in 2015 ?

TNS Retail Forward forecasts 15 trends that will redefine the retail business environment:

\section{The Downsizing of (Almost) Everything}

Expect (almost) everything except mega-store chains and formats to downsize during the decade-products/packaging, retail chains, store footprints, living spaces. The sustainability trend will drive the downsizing of products, packaging, resource consumption and waste. More people will look for smaller, more personalized spaces - both to live and to shop. Accessibility to almost infinite choices (at least online) and the growing ability for consumers to remix, adapt or create what they cannot find will splinter much of mainstream retailing into smaller niche offers - down to units of one.

\section{The Glocalization of Retailing}

For many big retailers, the next growth phase will be about segmentation and localization. Big retailers of the future will get there by operating multiple formats and multiple concepts, targeted to specific customer segments, in specific local markets, for specific end-use needs and occasions, while operating in specific shopping modes. Retailers will need to combine global market savvy and sourcing with local market delivery and know-how.

\section{Breaking the $80 / 20$ Rule}

The future of retailing is selling less of more. Aggregation of small will be the new big. The traditional rule of thumb that $20 \%$ of SKUs equals $80 \%$ of sales will no longer be the rule. In 2015 , the other $80 \%$ of units will represent an increasing share of the sales and a disproportionate share of the profits. With expanded access, consumers will buy less of what's "popular" and more of what "suits me." Retailers that can figure out how to deliver what niche markets are looking for will reap the profits. "Now you see it, now you don't" (limited editions, fast fashion, customization, et. al.) will replace "stack it high and let it fly" as the profitable retailer's mantra.

Niche concepts will flourish on the Internet, benefiting economically from an environment that effectively aggregates far-flung, widely dispersed, even global demand. More niche retailing will populate the bricks-and-mortar world, as specialty retailers target finer niches with bigger portfolios of smaller footprint, smaller store count, more narrowly focused concepts. Fresh, new resources will find routes to market in alternative venues that emerge to showcase the latest trends (rent-a-stall/case, designer flea markets, roving trunk shows, store-in-store) and, of course, via the Internet. 


\section{The Unchaining of Retailing}

Size does not equal success in 2015 . We will see the demise of the cookiecutter specialty chain. The day of the 1,000-outlet specialty chain delivering the same homogenous, narrow and deep assortment everywhere, regardless of location, is over. Chain size will top out at lower store counts. Retailers will expect to achieve more of their growth from new concepts than from established concepts. The new specialty mega-retailer will comprise an everevolving portfolio of concepts that are fleet of foot and always keep a finger on the pulse of consumer segments. Specialty retailing will be reincarnated by going back to its roots and getting closer to the customer.

To spur growth, many specialty retailers will follow extension avenues that help maximize customer value and leverage organizational skills-e.g., a series of lifestage concepts designed to sustain a lifelong relationship with the customer (and his/her progeny); new product and service concepts that help serve all of a customer's lifestyle needs; or concepts that leverage lifestyle/ stage expertise and capabilities at different price tiers.

\section{Global Consolidation of Big Box Retailers}

Big box retailing doesn't go away in 2015, but expect to see even greater concentration of market share on a global scale. Those players that remain after consolidation will be stratified by price tier and lifestyle. They will position strategically as share of life portfolios designed to meet target customer lifestyle or lifestage needs inside a single box. They will target modular flexibility inside the box and multi-channel reach around the box. They will operate multi-format extensions of the box to meet different customer needs, occasions and shopping modes.

\section{Share of Life Retailing}

Retailers will define themselves by the customers they serve, rather than by the products they sell. Retailers will grow by positioning themselves as more than just purveyors of "stuff" but also as one-stop purveyors of lifestyles or need states. Service offers will help bring the brand experience to life. The new one-stop shop will focus on customer segments with edited assortments, simplified choices (eliminating the "tyranny of choice"), and new combinations of goods and services. Do-it-for-me service and solution offers will surge as retailers strive to capture a share of the growth in spending on services. Service offers will help buffer retailers from falling margins as products become more commoditized and price-competitive. More retailers will leverage their brand license into the realm of services, making the next concept in their portfolio one that sells services, not products. More retailers will emphasize end-to-end brand experiences-encompassing pre-purchase, point-of-purchase and after-purchase. They will target not only ease of shopping but also ease of use. 


\section{The "Un-storing" of Retailing}

It will get harder to answer the question "what's a store" - much less "what's in a store." Multi-channel will multiply-covering more than stores, catalogs and an online presence-and come to mean a bigger, broader brand presence. Distribution and marketing models will proliferate. Harbingers include pop-up stores, virtual stores, and retailers partnering with service/ experience purveyors (e.g., spas, cruises, hotels) or developing their own. Stores as we know them increasingly will exist primarily to provide brand experiences and immediate fulfillment. The definition of "store" will expandencompassing inventory-less stores, "endless aisle" in-store kiosks that customers can shop for extended product lines and hard-to-find SKUs, drivethroughs and touch-screen windows that take orders, store-within-a-store retailers that live in host facilities, retailers that sell services (not stuff), and more.

\section{The Rise of the Anchor Place}

Like the store of the future, the shopping center of the future will be closer to the customer. We will see the demise of the anchor store as the main draw. The place becomes the destination. New generation lifestyle centers will offer the ultimate in simplification and convenience-a "pre-packaged total lifestyle experience" where busy consumers can shop, work, socialize, eat, be entertained, live. New tenant mixes and anchors will focus on customer lifestyles, not just customer shopping styles. These centers also will provide a sustainable (cost-effective, resource-efficient) response to the land-use dilemmas of the future-when anticipated population growth will outstrip available land mass if suburban growth continues in the current mode.

\section{Consumer as Co-creator}

The line between maker and consumer will blur. Consumers will have almost limitless opportunity to get what they want by participating in the value chain as creator, co-creator, adapter, editor, re-mixer and re-packager. Unprecedented levels of customer connectivity-pre-manufacture, pre-shop, while shop, post-shop-will actively engage consumers in the development and customization of their own products, media and shopping experience. We will see more customer-driven R\&D, more mass customization, more personalization and more onsite "manufacturing." Personalization will thrive in the digital world, unhampered by time and materials costs, but more and more brick-and-mortar offers will benefit by incorporating personalization options into the mix, as well. 


\section{Exclusivity Escalates}

Penetration of private brands and manufacturer exclusives will explode across virtually all categories as retailers require differentiation, versatility, newness and return on inventory investment. Private brands will be key as retailers strive to satisfy niche opportunities, enable customization and keep pace with here today-gone today trend lifecycles. Umbrella brands will enable retailers to put their stamp on an expanded range of product and service offers. More retailers will invest in vertical end-to-end supply chain capabilities or require seamless virtual supply chain capabilities with manufacturers when it doesn't make sense to do it themselves.

\section{Suppliers Defend Turf}

In 2015, suppliers will live by two credos: "The best defense is good offense" - and - "If you can't beat them, join them". Supplier-retailer relationships will be increasingly collaborative but also increasingly competitive. Branded supplier-retailer partnerships will multiply but so will retailer private brands. More retailers will use or license brands to convey credibility. More suppliers will work vertically with retailers on unique brand and product offers-sourcing through selling.

Suppliers will gain back some of the power they have ceded to retailers in the past decade. With the Internet, consumers will have visibility into the full supplier offer-not just what is on the retail shelf-de facto emerging as the ultimate consumer-pull strategy. The next step for suppliers will be to provide consumer access - anything they can see they can buy. Some will go supplier direct. Some will work with retailers to ensure the products consumers want reach the retail shelf (real or virtual). Also expect more suppliers to set up shop as retailers - although the retailer will never be completely disintermediated in some categories, such as groceries, where product aggregation is critical to shopping experience and efficiency. It will be incumbent on suppliers to engage consumers to build brand and product relevance.

\section{Power to the People}

Tools and technology will change the balance of power in retailing, shifting the power to the people. Consumers will have almost perfect information access about products and pricing. It will be almost impossible for retailers and producers to maintain a significant difference in margins on widely distributed commodities, underscoring the importance of differentiation, innovation, and integrated lifestyle approaches to doing business. Consumers will wield clout through social networking, value chain involvement and aggregation. Expect to see the reincarnation of group buying - not for B2B, but for B2C. Expect consumers to want almost perfect product access - what they want, when 
they want it, in the size they want it, at the price they want to pay for it, at the place they want to shop for it. If they can't find what they want, they will expect the opportunity to conceive or create it.

\section{New Technological Environment}

Technology will pervade the living and shopping experiences of 2015. Most of the technology trends anticipated for 2015 are progressions of trends that are under way today; they will just be more ubiquitous-tools and technology within reach wherever, whenever and for whatever purpose.

Consumers can expect to shop location-free-via wireless broadband, wireless devices and instant translation. They can expect to shop intervention-free-via digital homes, networked appliances, automatic replenishment, man-machine interaction and device-to-device communication. Social networking will evolve into profitable business models that give consumers more control over what retailers sell and what suppliers make.

Technology will help customers enjoy a more personalized shopping experience via customization options, fit/size scanners, and fitting rooms outfitted with touch-screen connectivity to request different sizes or items, social networking via live video and virtual try-on options. In-store technologies will help create a more efficient and engaging shopping experience, via such options as holographic sales assistance, smart carts, product and information access kiosks, interactive digital media and messaging, biometrics and other forms of instant payment.

Also expect the emergence of location-based advertising that will tap into prospective customers on a permission basis, based on knowing their location through their mobile devices. Companies will be able to send consumers relevant offers while they are en route and drive measurable sales.

\section{Value Chain Evolution}

Today's value chain is designed for mass merchandising. The value chain of 2015 will need to support niche merchandising, down to the location, day part and customized individual unit. It will be defined by connectivity, early capture of true demand signals, total visibility, shared data, real-time information, real-time response, decentralization and integrated shared logistics. It will enable much clearer insight into true demand via the proliferation of interactive "Choiceboards" designed to help consumers see and select from the full extent of product options available. We will see a transition to "true demand" (what the customer wants vs. what the 
customer was forced to buy) and a transition to lean consumption (minimizing waste by producing to demand).

\section{Triple Bottom Line Scorecard}

Retailers and suppliers will need to become better global citizens. In 2015, the definition of corporate success will take into account environmental and social performance in addition to financial performance. Retailers and suppliers should expect to be measured against an expanded set of criteriaplanet and people as well as profit. Companies will be evaluated on how well they meet the needs of a wide variety of global stakeholders-customers, employees, suppliers, investors, communities and regulators. They will be judged on how well they manage and conserve increasingly scarce resources and how effectively they meet rising safety and wellness standards. 
What must retailers and suppliers do to succeed in the new landscape of 2015?

Recent history focused on efficiencies in the form of technology, operating strategies and sourcing strategies. This is a fundamentally mature strategy, with most companies at parity. It is also fundamentally a mass marketing strategy.

The challenge for retailing in 2015 will be to manage complexity and diversity-businesses that span the globe while reaching out to the niche of one.

This will require focus on a new set of strategic capabilities and solutions:

\section{Shopper Insights}

Understanding shoppers will be more critical than ever in 2015. Given the anticipated growth of niche retailing, the diffusion of media and markets and the increasing reliance on point of sale as point of communication, shopper insights captured in the retail environment will be key to driving sales.

Retailers will need to understand what motivates the shopper at the point of sale. Suppliers will need to work with retailers to determine exactly where a product fits within the retail mix - and how that product will help drive sales and profits. 
Understanding consumers is not the same as understanding shoppers (Figure 19). Conventional consumer research typically focuses on who is shopping for which products and where. Shopper insights research is about understanding the needs, attitudes and behaviors of customers in shopping and buying mode-why the shopper buys (or does not buy), why certain items were purchased (and why other items never had a chance) and how the shopping experience affected the buying decision.

\section{Figure 19}

The Shopper Insights Process
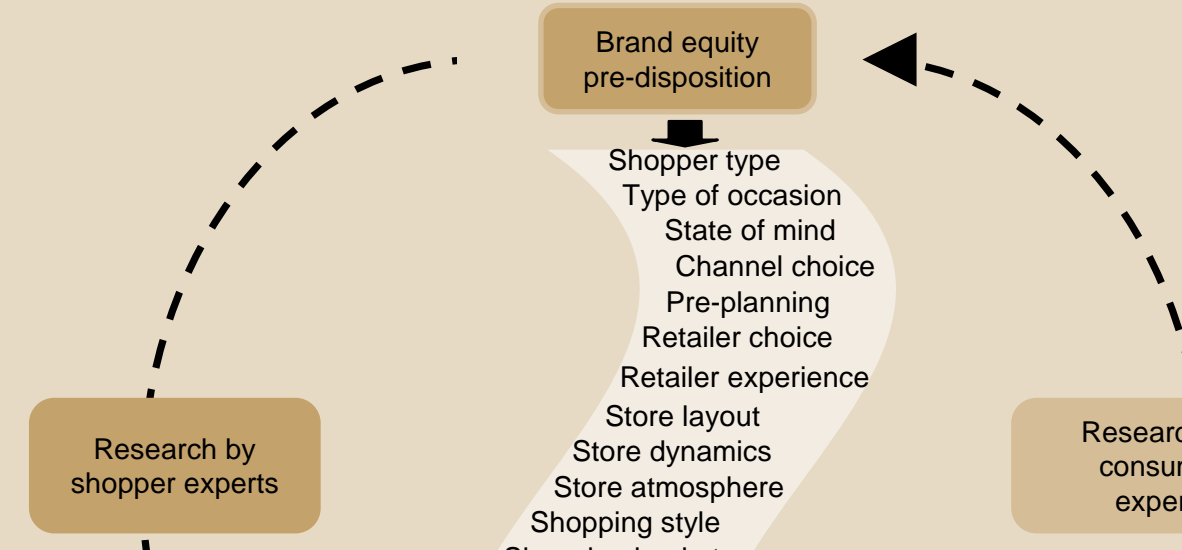

Store layout

Store dynamics

Store atmosphere

Shopping style

Shopping basket

Shopping route

In-store advertising

Shelf layout

Signage

Promotions

Pack standout

Pack communication

potentially be impacted at

each stage of journey

Source: TNS Retail and Shopper Insights 


\section{Data Analytics}

During the next decade, retailers must learn to wield the customer databases they have been building as powerful customer knowledge, marketing and merchandising tools (Figure 20). With the growth of niche retailing and the proliferation of customer touch points, retailers will have more data points than ever. They will need to harness this information to do business in ways that are customer-centric rather than operations-centric. Sophisticated data analytics will help retailers and suppliers mine shopper wants, needs and purchase histories in order to provide more personalized, relevant offers to the shoppers. It will help retailers and suppliers mesh multiple sources of shopper information to identify correlations and patterns for strategic decisions.

Figure 20

The Data Analytics Process

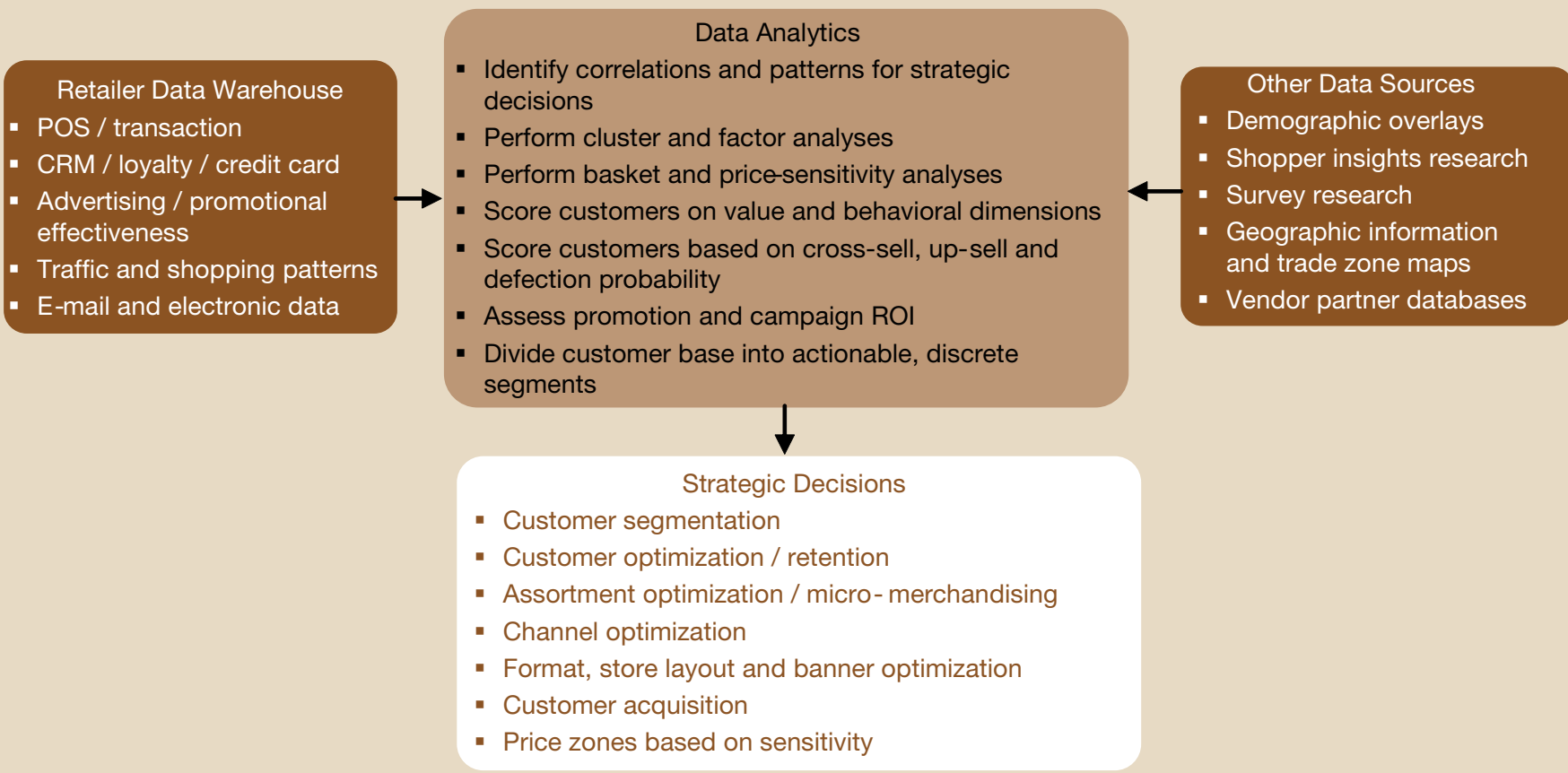

Source: TNS Retail and Shopper Insights 


\section{Innovation}

Innovation is the one true sustainable driver of growth. Too many companies have focused on making better products, when real advantage comes from making different products and better product experiences. Effective innovation integrates an understanding of how consumers live, how they buy and how they use the products they buy (Figure 21). In 2015, trends are here today, gone today. As product lifecycles grow shorter, the need to innovate will intensify.

Innovators in 2015 will replace mass production with extremely limited production, extremely limited availability and rapidly evolving portfolios of extreme niche concepts. They will offer new combinations of products, experiences and services that let shoppers express themselves. Increasingly, innovation will take place at the point of purchase, by enabling customization and personalization.

Trend identification becomes a critical success factor. Trendspotters will need eyes where the action is-online, where filters help point to the next trend; on the ground, in emerging markets of influence; and via engagement marketing, to actively solicit input from consumers.

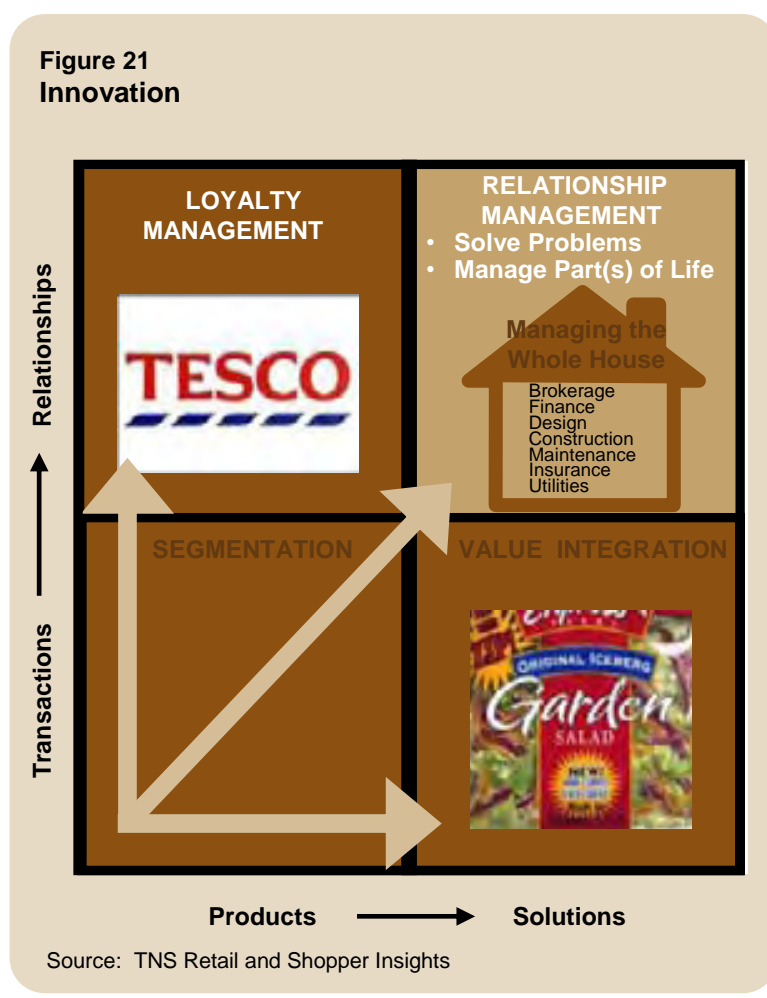

\section{Shopper Experience}

In an era of almost perfect production and almost perfect accessibility, especially in developed markets, experience, like innovation, will drive retail value. In emerging markets, expanding accessibility driven by modernization of retailing will continue to add value. Customers today usually don't want (or need) a better product - they want a better shopping or product experience. Companies will need to focus on how customers ultimately feel about themselves in their interaction with the shopping environment, product, service and brand (Figure 22). This is a result of the end-to-end brand experience:

- Pre-shop-how effectively the customer is engaged

- Shop-ease, enjoyment and relevancy of the retail offer and environment

- Purchase-ease of transaction

- Post-purchase-ease and enjoyment of use, satisfaction of expectations 
Figure 22

Retail Value Curve

\section{Traditional Retail Value Curve}

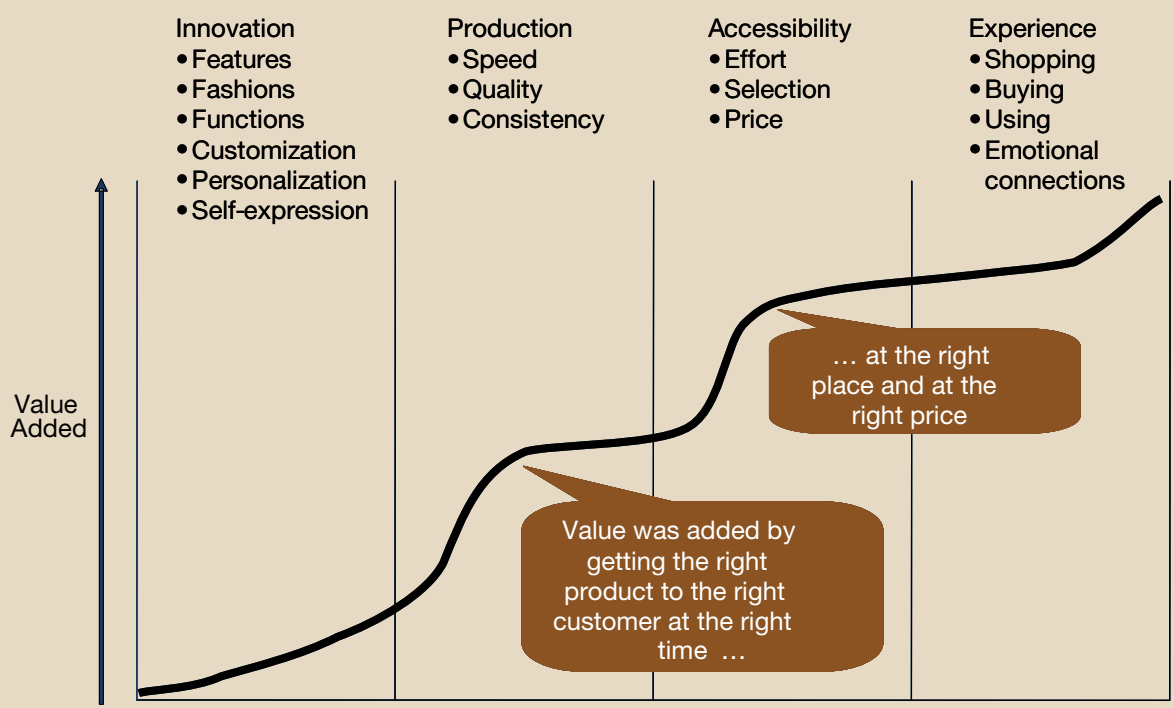

\section{Retail Value Curve}

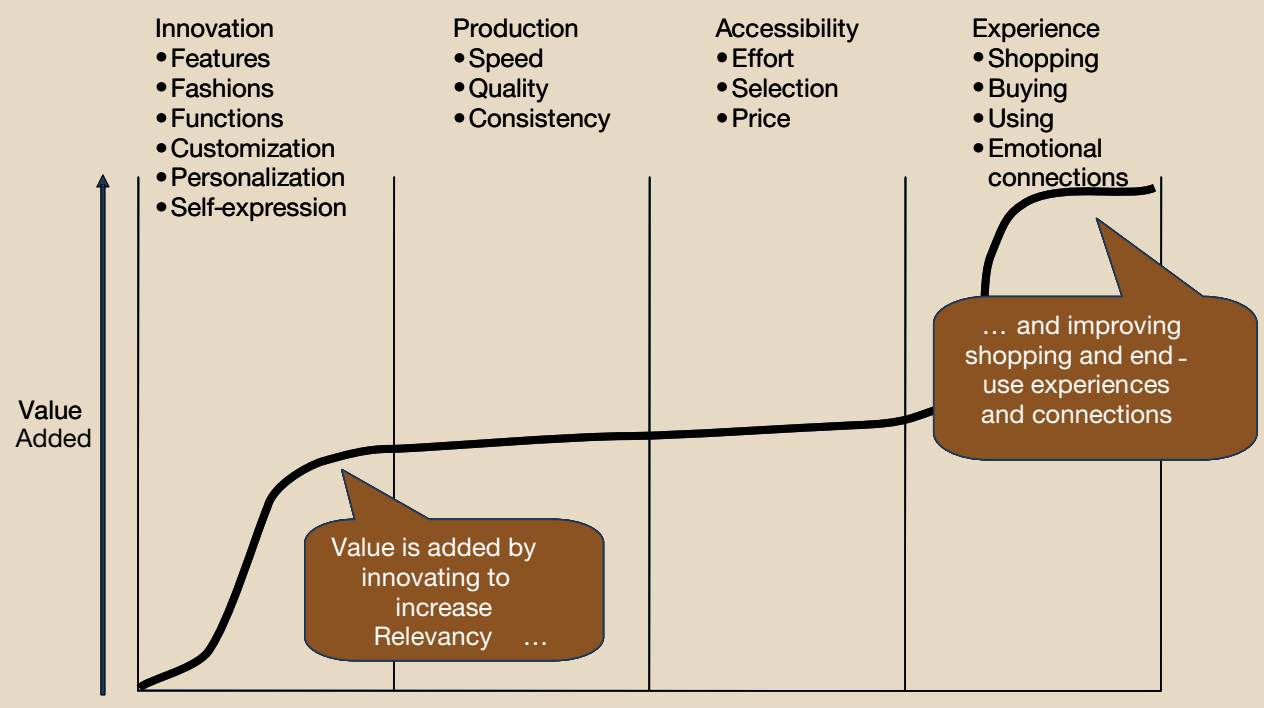

Source: TNS Retail Forward 


\section{Last-Mile Solutions}

Getting it there gets harder in 2015. Superior distribution will help define retail success in an era of global reach, niche retailing and accelerated lifecycles. Sales of customer-targeted niche products and of customized and personalized products should be more profitable in the long run, but only if sellers can get niche purchases to the customer efficiently-or give the customer a reason to pay for them. In a digital distribution model, the cost of getting a product to the consumer falls precipitously (approaching or even reaching zero). But in a physical distribution model, the delivery costs and time constraints remain. Between now and 2015, expect a boom in rapid delivery service options. Also expect a groundswell of alternatives including finely targeted niche concepts, micro-merchandising and onsite customization.

\section{Speed}

Today is "too late" in 2015. In an era of extremely reduced cycle times, shorter time to market becomes a critical success factor. Retailers and suppliers will need to use predictive tools to stay ahead of the curve. They will need to identify and act on trends early. They will need to get into trends quickly - and out of trends more quickly.

\section{Small-Scale Economies}

For most of the history of retailing, scalar economy and scalability have referred to the efficiencies of mass production and retailing. In 2015, they will need to refer to efficiencies of niche production and niche concept operation-down to the single unit. Unit production will burgeon in the digital world, unrestricted by time, material and delivery costs. Ability to achieve economies of small-scale operation and individual production increasingly will help define success in the physical world.

\section{Risk Management}

"Stuff" happens. Data security breaks, product contamination, workplace accidents - the possibilities are endless. In a networked world, when something goes wrong, bad news spreads quickly. Companies need to be prepared to control their responses to uncontrollable situations. 
Additionally, as many retail organizations will be composed of multiple concepts, retailers will increasingly need to think of these concepts as elements of an investment portfolio that need to be actively managed throughout their lifecycle in order to maximize $\mathrm{ROI}$ and minimize risk.

\section{Financial Flexibility}

Expect privatization to replace IPOs as the financial strategy of the decade. Retailers and suppliers can expect to be under more scrutiny from more stakeholders in 2015. Traditionally the public eye has not looked kindly on change and experimentation. Whether because more retailers are approaching the end of their rollout runway or because fewer companies will try to roll out new concepts rapidly in cookie-cutter mode, expect fewer IPOs. Many retailers will go private, as they seek to avoid scrutiny and gain greater flexibility while downsizing chains, waxing and waning new concepts to meet demand trends, and transforming on a regular basis.

\section{Triple Bottom Line Accountability}

Corporate eyes are opening to the triple bottom line (people, planet, profit) accountability challenge. It is the accounting that remains a hurdle. The costs are definable, but the return on investment is harder to quantify. In an era of increased transparency and scrutiny, retailers and suppliers will need to focus not so much on the cost of operating responsibly but on the cost of not doing it. The intangible benefits of the triple bottom line are clearimproved corporate reputation, enhanced brand equity, higher employee morale, increased customer goodwill. But, wherever possible, companies also must demonstrate the direct connections between new sustainability and stakeholder initiatives and increased savings, sales and profits.

\section{Managing Complexity}

Managing complexity will be the key to doing business successfully in 2015 . Retailers and suppliers will be more global, more diverse, and operate across more channels.

Companies will need to think big but act small. Management will need to evolve to a more distributed model-managing across geographic, cultural, legislative and regulatory boundaries; responding to local tastes, customs, 
traditions, lifestyles and economies. Management will need to be flexible and responsive-move quickly, partner to extend reach, focus on core capabilities, outsource non-core activities. Management will need to be situationsensitive - to the needs, wants, tastes and preferences of a wide variety of stakeholders inside and outside the company.

It will be critical for management to embrace technology:

- Technology to extend reach-no longer will retailers need a physical footprint to have market presence.

- Technology as filter - "hearing aid" to what shopper niches are looking for, conduit to the next best thing. 
For companies that can manage complexity and respond to market forces, 2015 will be a time of tremendous growth opportunities. The companies most at risk will be the incumbent leaders - if exploitation of existing opportunities causes inertia on newly emerging opportunities.

In 2015, the market will talk to the retailers and suppliers that tune in:

- Consumers will tell you what they want-if you know where to listen

- More places to listen to consumers and spot trends

- More tools and technologies to enable more focused responses

- Greater opportunity to be specific, individualized and relevant 


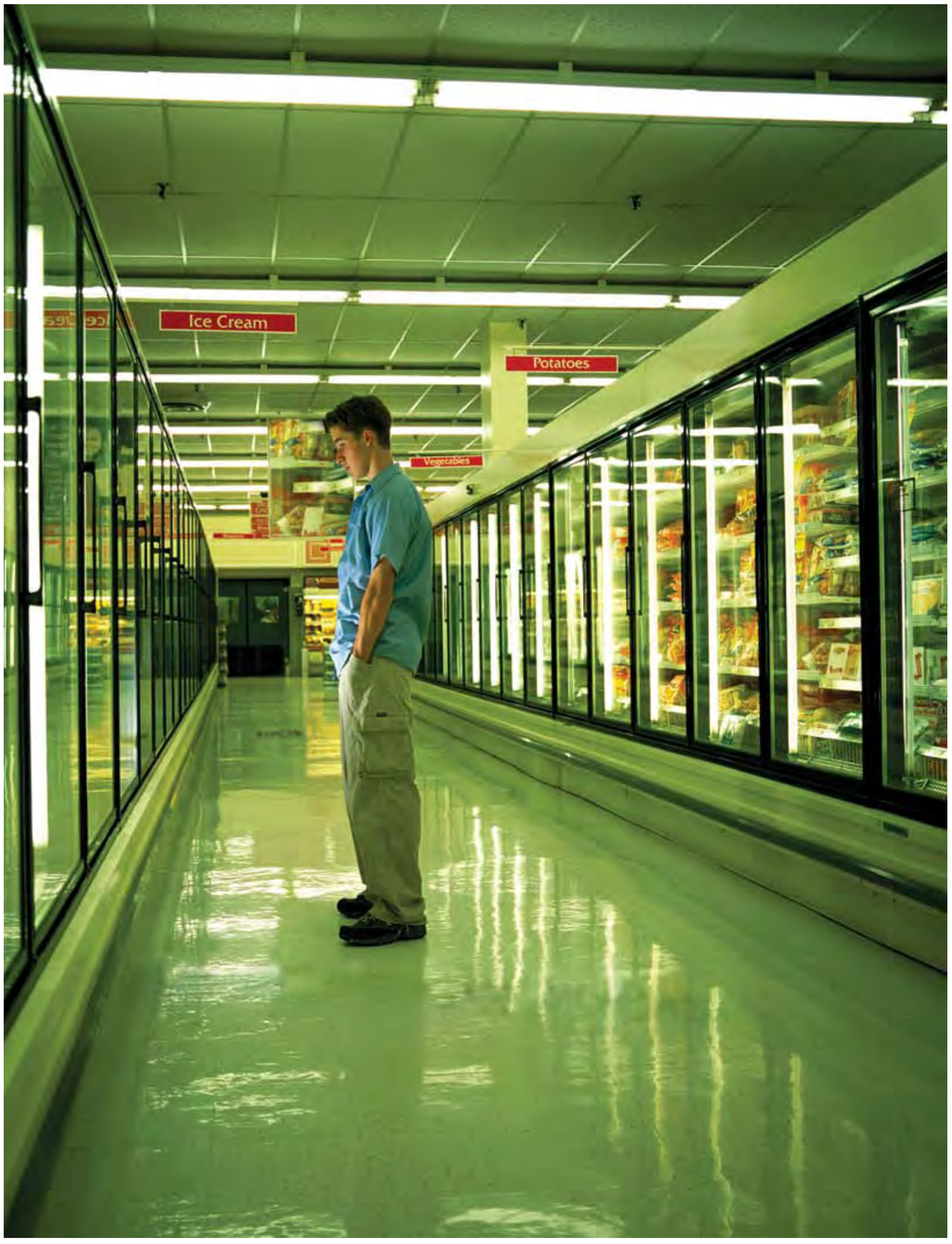




\section{PricewaterhouseCoopers contributors}

\section{John Maxwell, Americas Retail \& Consumer Industry Leader}

John Maxwell is a senior PwC partner with more than twenty years experience serving large multinational consumer products companies and retail clients. $\mathrm{He}$ is both the Global Consumer Packaged Goods Industry Leader and the Americas Retail \& Consumer Industry Leader, with responsibilities for developing and managing the Firm's practice among all R\&C clients including new services and business development, Thought Leadership, overseeing the Knowledge Management program, developing training for the Firm's industry professionals, and maintaining relationships with key trade associations.

\section{Lisa Feigen Dugal, North American Retail \& Consumer Industry Advisory Leader}

Lisa Feigen Dugal is the co-leader for Retail \& Consumer in the U.S. Advisory Practice as well as the Advisory Point partner for a key CPG account. With twenty years of Advisory experience, Lisa leads a team of experienced professionals focused on improving performance for their clients in procurement and the supply chain, and directs a broad range of process and technology improvement engagements with a focus on consumer products and pharmaceutical companies. Lisa led PwC's Strategy and Change group for a number of years, aligning back office services and generating indirect spending savings.

\section{TNS Retail Forward contributors}

\section{Elaine Pollack, Principal Author}

Elaine Pollack is Executive Vice President of TNS Retail Forward. Elaine has more than 30 years of consulting experience with retailers and consumer products companies. She specializes in strategic planning and marketing research and analysis designed to identify and characterize opportunities for business development and profitable sales growth. She graduated Phi Beta Kappa from Douglass College of Rutgers University with a Bachelor of Arts degree in English and holds a master's degree in English literature from Columbia University.

Other TNS Retail Forward contributors include: Rob Gallo, Lois Huff, Tom Rubel, James Russo, Dan Stanek, Kelly Tackett and Mary Brett Whitfield. 


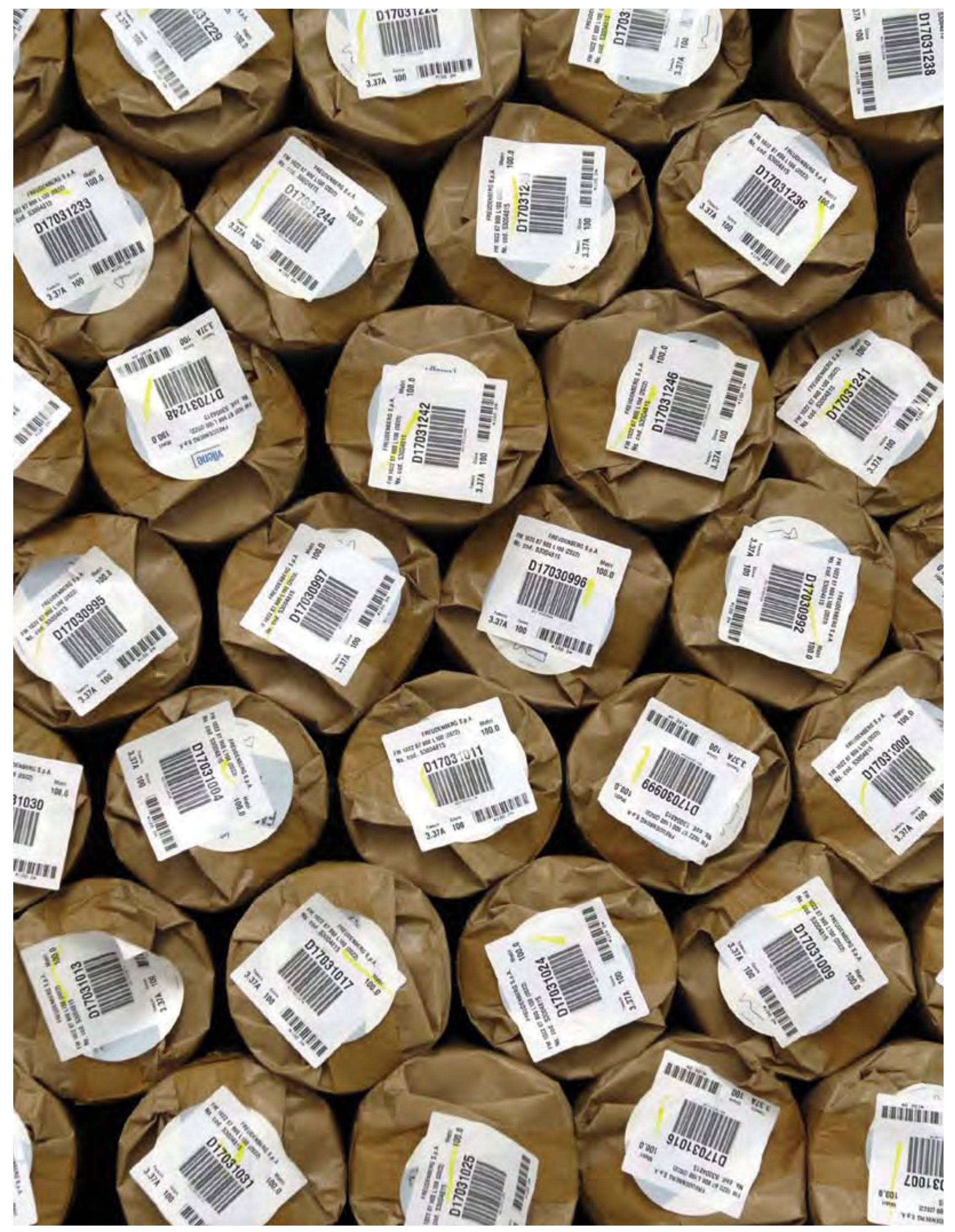


PwC and TNS Retail Forward professionals are available to discuss the data, analysis and commentary in this report, as well as help you address the opportunities discussed within.

For further information, please contact:

John G. Maxwell

Americas Retail \& Consumer Industry Leader

PricewaterhouseCoopers, LLP

(973) 236-4780

Lisa Feigen Dugal

North American Retail \& Consumer Industry Advisory Leader

PricewaterhouseCoopers, LLP

(646) 471-6916

Tom Rubel

President

TNS Retail Forward

(614) 355-4004

(c) Copyright 2007 PricewaterhouseCoopers LLP and TNS Retail Forward. All rights reserved. Reproduction of Retailing 2015: New Frontiers in any form is prohibited except with the prior written permission of both PricewaterhouseCoopers LLP (PwC) and TNS Retail Forward. No part of this work may be reproduced or transmitted in any form or by any means, electronic or mechanical, including photocopying, recording, or by any information storage and/or retrieval system, without permission in writing from the publisher. This work may contain data used from a third-party source. However, the data used from third-party sources has not been independently verified, validated, or audited by PwC and is provided 'as is'. PwC and TNS Retail Forward do not guarantee the accuracy, authenticity, adequacy, completeness, or availability of any information and are not responsible for any errors or omissions or for the results obtained from the use of such information. PWC AND TNS RETAIL FORWARD, AND THEIR RESPECTIVE AFFILIATES, EXPRESSLY DISCLAIM ALL WARRANTIES OF ANY KIND, WHETHER EXPRESS OR IMPLIED, INCLUDING, BUT NOT LIMITED TO THE IMPLIED WARRANTIES OF MERCHANTABILITY, FITNESS FOR A PARTICULAR PURPOSE AND NONINFRINGEMENT. All content is provided 'as is'. Your use of Retailing 2015: New Frontiers is at your sole risk. No professional service or advise is provided or shall be deemed to be provided by means of this content. You expressly understand and agree that PwC, its Affiliates, member firms, partners, employees or agents shall not be liable in no any event, either jointly or severally, for any direct, indirect, incidental special, exemplary, punitive or consequential damages in connection with any use of the Retailing 2015: New Frontiers, regardless of the theory of law on which such claim may be based.

"PricewaterhouseCoopers" refers to PricewaterhouseCoopers LLP (a Delaware limited liability partnership) or, as the context requires, the PricewaterhouseCoopers global network or other member firms of the network, each of which is a separate and independent legal entity. 
pwc.com 